\title{
Assessment of tectonic control on the development of low mountains moderate relief in the Outer Carpathians (Southern Poland)
}

\author{
Janusz GODZIEK1 ${ }^{\text {iD }}$ https://orcid.org/oooo-00o2-0525-4451; e-mail:j.godziek23@gmail.com \\ Krzysztof GAIDZIK* iD https://orcid.org/oooo-0oo3-3286-o833; e-mail: krzysztof.gaidzik@us.edu.pl \\ ${ }^{*}$ Corresponding author \\ 1 Faculty of Natural Sciences, University of Silesia, Będzińska 6o, 41-20o Sosnowiec, Poland \\ 2 Institute of Earth Sciences, University of Silesia, Będzińska 6o, 41-20o Sosnowiec, Poland
}

Citation: Godziek J, Gaidzik K (2020) Assessment of tectonic control on the development of low mountains moderate relief in the Outer Carpathians (Southern Poland). Journal of Mountain Science 17(10). https://doi.org/10.1007/s11629-020-6121-4

(C) The Author(s) 2020.

\begin{abstract}
Inherited tectonic structures, ongoing tectonic deformation, and variations in relative rock uplift rates play an important role in conditioning the processes of relief development. Their influence among other factors, such as climate and lithology, can be quantified using landscape analysis, and geomorphometric indices, in particular. The usage of landscape analysis in recent years is increasing systematically due to the constant improvement of the digital elevation models and GIS software that significantly facilitate this approach. In this study, we aim to recognize the influence of tectonic structures and processes on relief development in the low mountains with moderate relief of the Sola River catchment in the Western Outer Carpathians. To this end, we calculated geomorphometric indices (river longitudinal profile, stream-length gradient index, minimum bulk erosion, relief ratio, circulatory ratio, elongation ratio, and hypsometric integral) for the Soła River and its 47 sub-catchments using a 25-m spatial resolution Digital Terrain Elevation Data Level 2. Additionally, we identified lineaments and knickpoints and correlated the computed results with local and regional fault networks, variations in lithology, and climate fluctuations. Obtained results indicate a significant impact of inherited tectonic
\end{abstract}

structures on the relief development of the Sola River catchment, i.e., directions of principal ridges and valleys follow the orientation of main folds and faults recorded in this area. Anomalously high values of minimum bulk erosion, river gradient, and streamlength gradient index allowed us to define two areas with higher relative uplift rates: 1) the Sola Gorge and 2) the Beskid Żywiecki Mts. Polish Outer Carpathians are generally considered as an area of low strain rate and low seismic activity. However, the possibility of neotectonic processes should be considered in geohazard estimations. Observed bends in the direction of river valleys that do not correspond with changes in lithology could be related to active strikeslip faults. These are probably the reactivated basement structures, copied in the thin-skinned nappe cover, as a result of the accommodation of the Mur-Žilina Fault Zone resulting from the tectonic push of the Alcapa (Alpine-Carpathian-Pannonian) microplate against the European plate. Thus, the role of recent tectonic activity in relief development of the Sola River catchment even though appears to be subsidiary at the most, should not be excluded.

Keywords: Tectonics; Landscape analysis; Relief development; Geomorphometric indices; Digital elevation model; Outer Carpathians 


\section{Introduction}

Worldwide examples proved the usage of landscape analysis and geomorphometric indices, in particular, to quantify the tectonic deformation and derive variations in relative rock uplift across high strain rate areas, such as the western USA, Taiwan, Himalaya, Andes, forearc of subduction zones, etc. (e.g., Burbank and Anderson 2001; Kirby and Whipple 2001, 2012; Keller and Pinter 2002; Gao et al. 2013; Gaidzik and RamírezHerrera 2017; Ramírez-Herrera et al. 2018; Wang et al. 2019; García-Delgado and Velandia 2020), and in low strain rate areas like SE Spain (e.g., Pérez-Peña et al., 2010), the Vienna Basin and central Pannonian Basin (e.g., Ruszkiczay-Rüdiger et al. 2009; Matoš et al. 2013), Sudetes Mts. (e.g., Różycka and Migoń 2017). Extensive and uncomplicated access to digital elevation models and GIS software essentially sustained the worldwide usage of numerous geomorphometric indices to discuss the response of landscapes to ongoing deformation (Keller and Pinter 2002; Font et al. 2010; Kirby and Whipple 2012). Observed anomalies in values of these indices result from tectonic activity, climate conditions, and variations in rock erodibility or changes in base-level (e.g., Burbank and Anderson 2001; Keller and Pinter 2002; Argyriou et al. 2017; Buczek and Górnik 2020).

Low mountains moderate relief of the Outer Carpathians is usually associated with no or low seismic activity. However, seismic events of generally small magnitude with long return periods occur here, as proven by instrumental and historical records (Guterch 2009; Plesiewicz and Wiszniowski 2015). Previous studies on relief development in the Outer Carpathians focused mainly on the impact of lithology and climate on mass movements (Margielewski 2006; Wójcik et al. 2006), landslide susceptibility mapping (e.g., Pawluszek and Borkowski 2017), and fluvial processes (Wyżga et al. 2016). Only a few studies suggested the possible influence of neotectonic processes on landscape evolution of the Outer Carpathians using river longitudinal profiles and drainage anomalies (Zuchiewicz 1998; Zuchiewicz et al. 2002, 2009; Płaczkowska 2014), river terraces (Olszak 2011), palaeomagnetic studies (Tokarski et al. 2016), lithology of Neogene and
Quaternary gravels (Tokarski et al. 2012). The Quaternary activity of faults in the Polish part of Carpathians has been proposed based on the analysis of fractured clasts (Tokarski and Świerczewska 2005; Tokarski et al. 2007, 2016; Zuchiewicz et al. 2011). DEM-based quantitative morphometric studies using GIS techniques are still uncommon in the Outer Carpathians (e.g., Vojtko et al. 2012), especially in the western segment. Moreover, the above-mentioned studies focused usually on the possible activity of neotectonic structures itself and not on the response of the landscape to ongoing deformation.

In this study, we aimed to recognize the influence of tectonic structures and processes on the morphology and drainage network in the Sola River catchment in the Western Outer Carpathians (Figure 1). Up to date, questions on the tectonic control on the landscape development in this area have not been addressed. Moreover, we attempt to understand the response of landscape to the possible impact of neotectonic structures with a low strain rate by studying the river network, as this is the most sensitive morphological element (e.g., Font et al. 2010; Gaidzik and RamírezHerrera 2017). For that, we calculated geomorphometric indices both, along the main rivers and their tributaries and across 47 subcatchments in the Sola River catchment. Our results indicate a significant impact of inherited tectonic structures and processes on the relief development of the Sola River catchment. Computed values of geomorphometric indices and the results of hydrographic network analysis suggest also the potential influence of neotectonic processes, probably related to tectonic push of the Alcapa microplate against the European Plate that leads to the NNE-oriented compression within the nappes of the Outer Carpathians, and the accommodation of the Mur-Žilina Fault Zone.

\section{Study Area}

\subsection{Location}

The Sola River catchment is located in southern Poland, bordering with Slovakia to the south (Figure 1B). It occupies an area of $1365.8 \mathrm{~km}^{2}$. Southern and central parts are in the Outer 

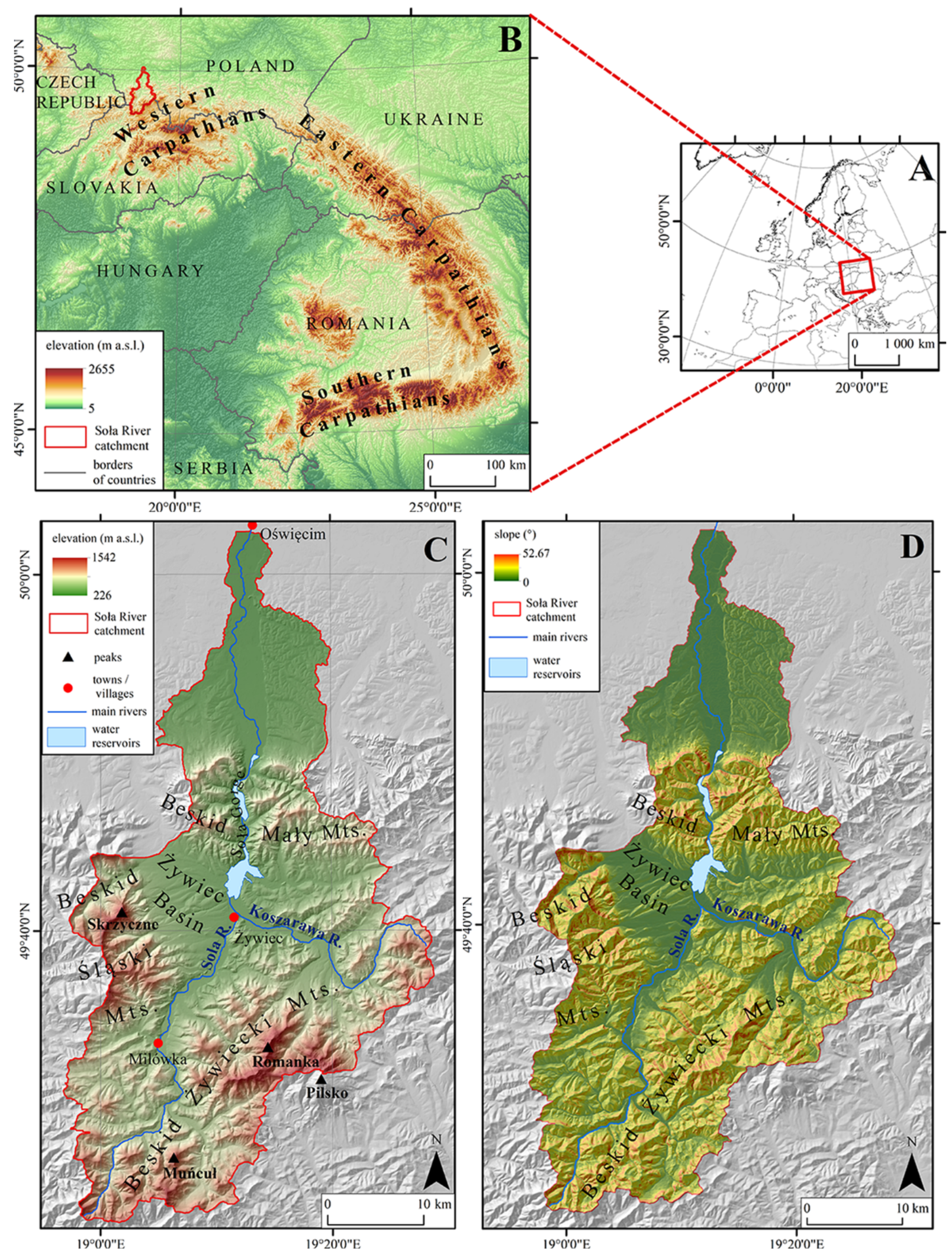

Figure 1 Location of the Sola River catchment (C) in the Western Carpathians (B) and Central Europe (A). Topography (C) and slopes (D) of the Sola River catchment. 
Carpathians, while the most northern part lies on the Carpathian Foothills. The 90-km long Sola River flowing from south to north is one of the right bank tributaries of the Wisła River, i.e., the longest river of Poland (Figure $1 \mathrm{C}$ ).

\subsection{Relief and climate}

Most of the Sola River catchment is characterized by low mountains with moderate local relief of $400-800 \mathrm{~m}$, known as the Beskid Mountains (Figures $1 \mathrm{C}$ and 2). In the northern part of the study area, the Sola River incises deeply into the mountain massifs forming the Sola Gorge (Figures $1 \mathrm{C}$ and 2A). Only the central (Żywiec Basin; Figure 2) and northernmost (Subcarpathian Basin) parts with lowland landscape at elevations of 200$300 \mathrm{~m}$ a.s.l. show low relative relief of $<100 \mathrm{~m}$. The absolute relief in the studied catchment varies from $226 \mathrm{~m}$ a.s.l. in the northern part of the catchment at the confluence of the Sola and Wisła Rivers, up to $1542 \mathrm{~m}$ a.s.l. in the south-eastern part on the northern peak of the Pilsko Mountain (Figure 1C). Slopes show generally medium gradient of $15^{\circ}-25^{\circ}$, reaching $<5^{\circ}$ at the ridges and in the valley floors, and $>35^{\circ}$ in steep valleys or

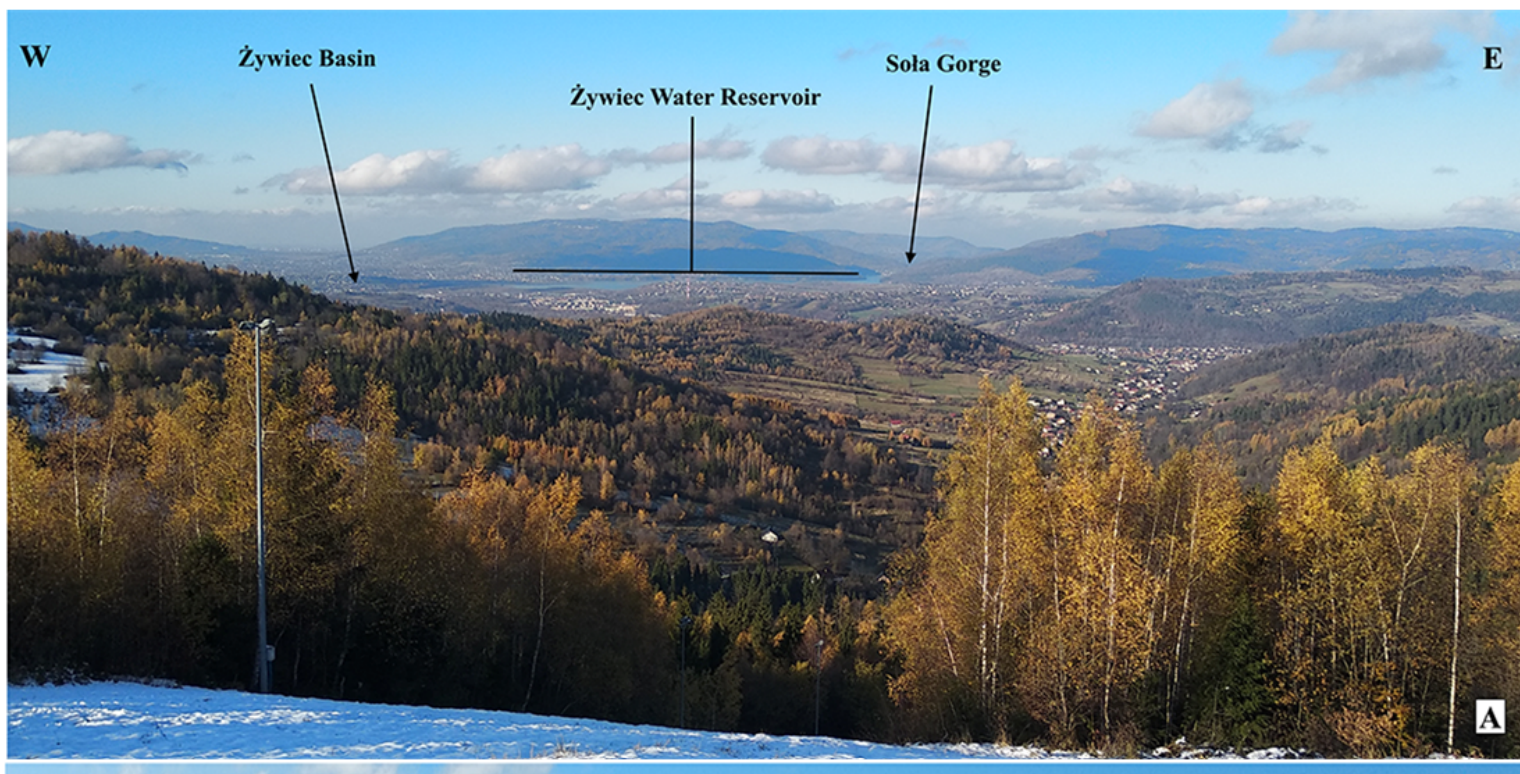

S

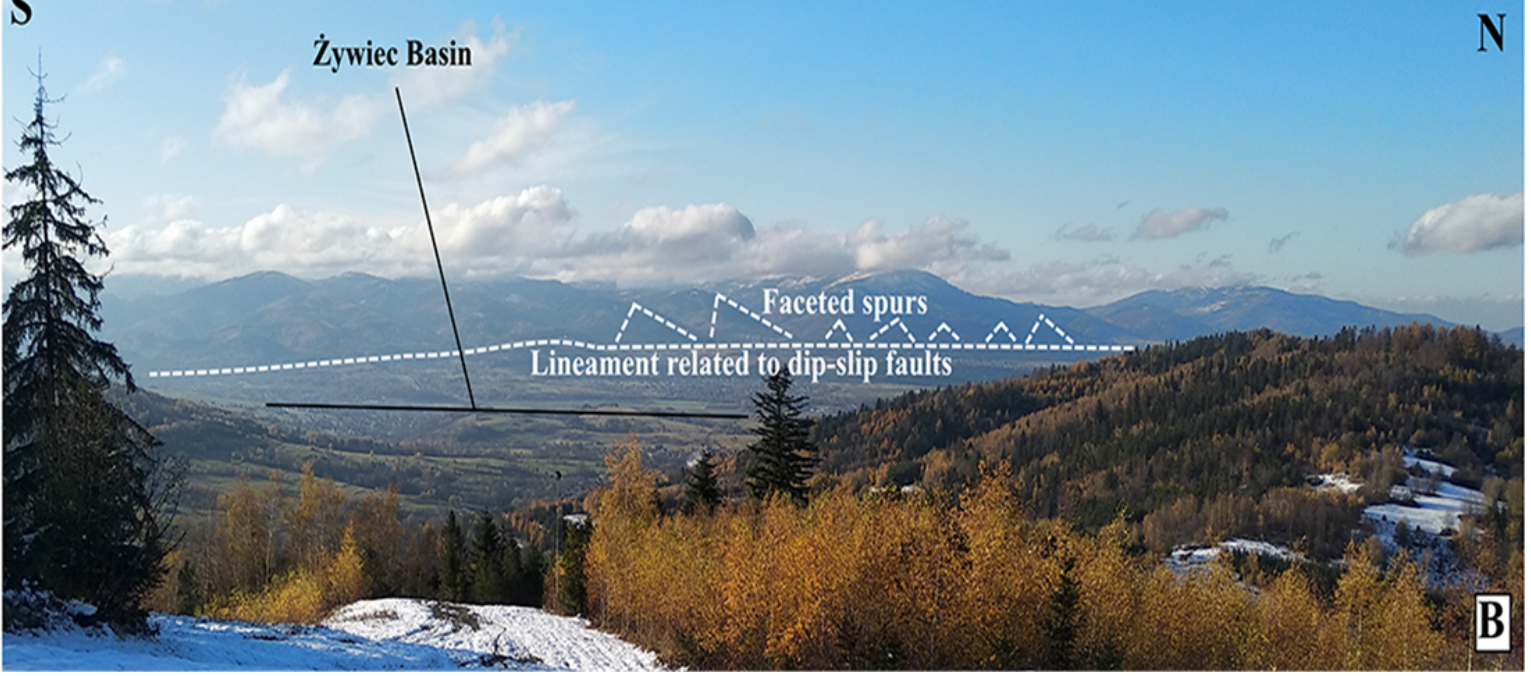

Figure 2 Photographs taken in the northern part of the Beskid Żywiecki Mts. presenting selected features within the study area: A - view to the north on the Beskid Mały Mts., showing the Żywiec Basin, Żywiec Water Reservoir and Sola Gorge; B - view to the west on the Beskid Śląski Mts. and Żywiec Basin with the faceted spurs marking the lineament related to the dip-slip fault. 

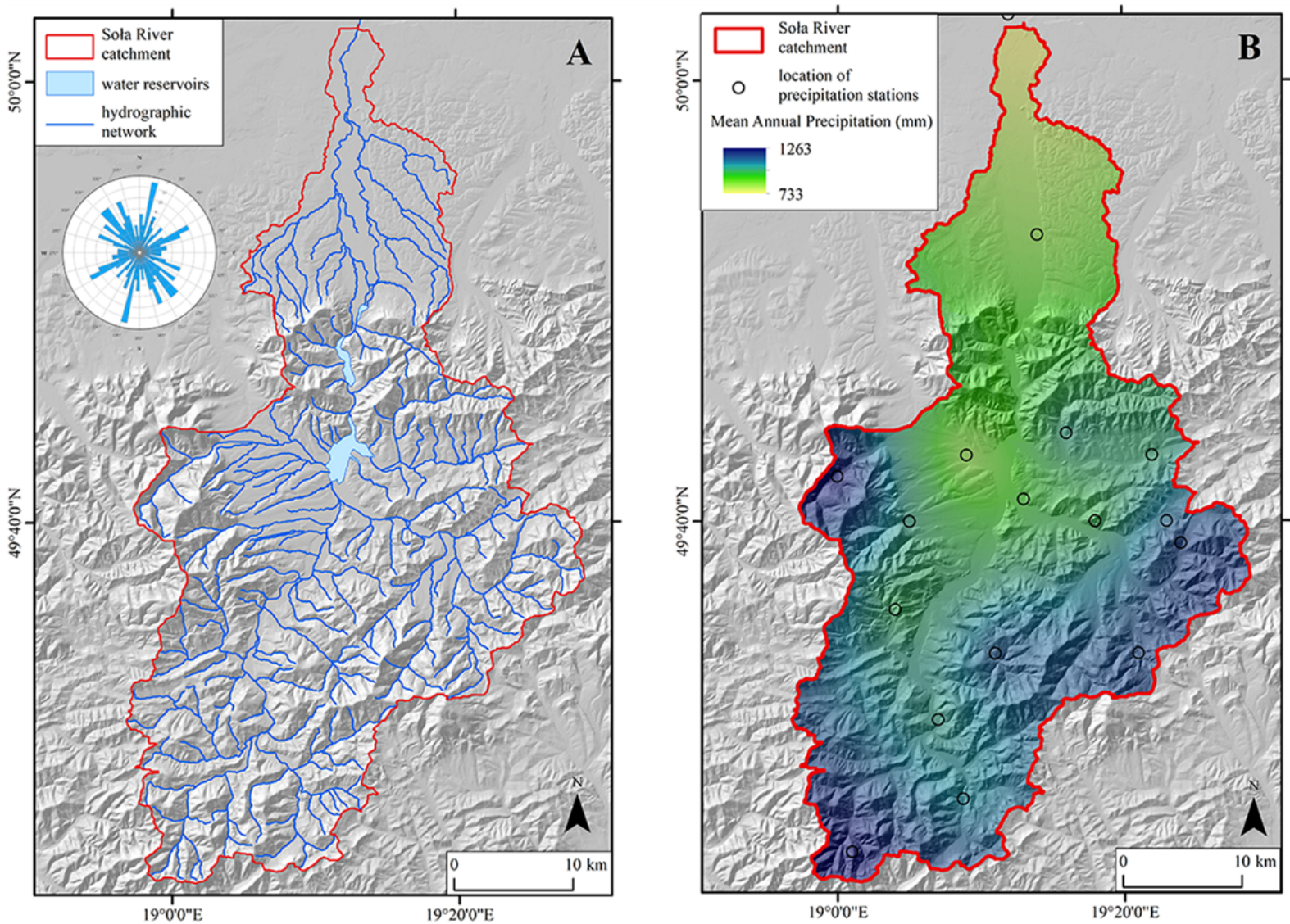

Figure 3 A - Hydrographic network and rose diagram presenting the principal directions of the river flow in the Sola River catchment (according to Computer Map of Hydrographic Division of Poland 2019). B - Mean annual precipitation in the Sola River catchment for the period 1950-2019. The source of precipitation data is the Institute of Meteorology and Water Management - National Research Institute (IMWM - NRI 2020).

landslide scarps (Figure 1D). The hydrographic network of the Sola River catchment is predominantly dendritic with trellis in the foothills (Figure 3A). Rivers flow predominantly towards the NNE, i.e. according to the general gradient direction. Also common are straight river segments directed: NW - SE and SW - NE (Figure 3A). The climate of the study area can be described as a warm transitional with significant influence of maritime air masses from the North Atlantic. Climate conditions here are strongly controlled by the elevation, as in any mountainous area. Mean annual precipitation varies between $<750 \mathrm{~mm}$ in the northern part of the study area to $>1100 \mathrm{~mm}$ in the western, southern, and southeastern parts of the Sola River catchment, which corresponds to the highly elevated parts of the mountains (Figures $1 \mathrm{C}$ and $3 \mathrm{~B}$ ). The mean annual temperature ranges between $8^{\circ} \mathrm{C}$ in the lowest areas and $4^{\circ} \mathrm{C}$ in the highest parts (Wypych et al. 2018). Early Pleistocene glaciations have reached the northernmost parts of the study area (Carpathian Foothills), thus the majority of the Sola catchment was not involved in glaciations. No evidence for glaciation has been found in the Żywiec Basin or adjacent mountains (Marks 2011).

\subsection{Lithology}

The Outer Carpathians are predominantly composed of the Upper Jurassic to Paleogene flysch sediments, including conglomerates, sandstones, claystones, shales, marls and cherts (Ryłko and Paul 2013). These are combined in numerous nappe structures extending from west to east, parallel to the deflection of the Carpathians and characterized by different rocks and variations in tectonic structures (Figure 4A). Five of these nappes can be distinguished in the Sola catchment, i.e., from the south to north: 1) Magura, 2) Grybów, 3) Dukla, 4) Silesian and 5) Subsilesian Nappes (Figure 4; e.g., Oszczypko et al. 2008). 

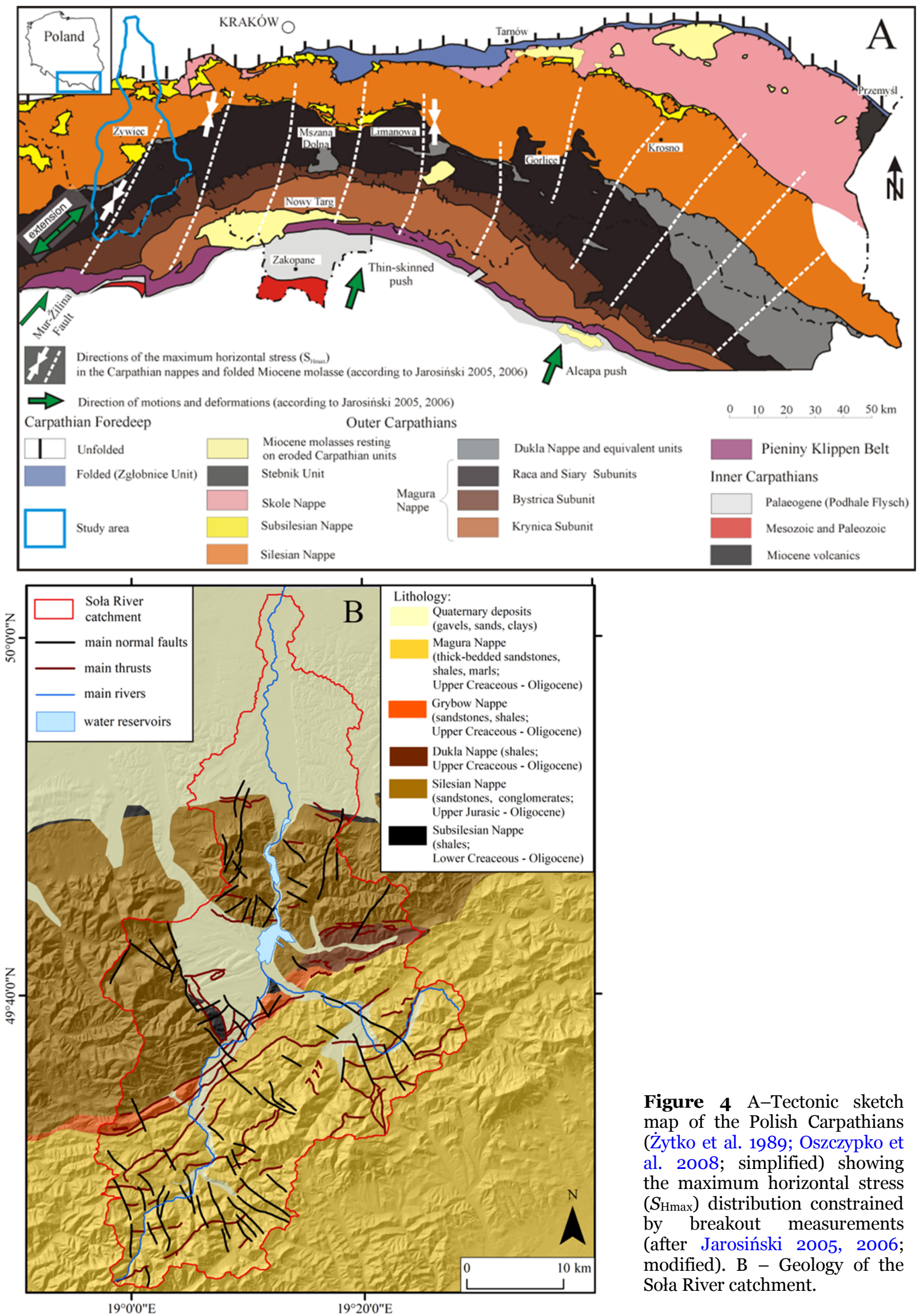

Figure 4 A-Tectonic sketch map of the Polish Carpathians (Żytko et al. 1989; Oszczypko et al. 2008; simplified) showing the maximum horizontal stress $\left(S_{\text {Hmax }}\right)$ distribution constrained by breakout measurements (after Jarosiński 2005, 2006; modified). B - Geology of the Soła River catchment. 
The Magura Nappe occurs in the southern and southeastern part of the study area and consists mainly of thick-bedded sandstones, shales and marls. The Grybów and Dukla Nappes are mainly built of shales and thin-bedded sandstones. The Silesian Nappe located in the central, western and northeastern part of the study area can be divided into two units: 1) the Godula Unit in the southern part formed of sandstones and conglomerates with the subsidiary amount of shales, and 2) the Cieszyn Unit in the northern part built of sandstones, shales, marls, limestones and intrusions of alkaline igneous rocks. The Subsilesian Nappe outcrops only in a narrow zone at the forehead of the Silesian Nappe in the northern part of the study area and in the Żywiec tectonic window in the central part of the studied catchment. Shale deposits (like siliceous shales and shales with radiolaria) dominate within this nappe (Książkiewicz 1977; Oszczypko 2004; Nescieruk and Wójcik 2013; Ryłko and Paul 2013).

The youngest deposits in the Sola catchment were deposited in the Late Neogene and Quaternary. Fluvial gravels, sands, and clays fill the valley bottoms. Colluvial deposits represented mainly by clays with rock debris commonly occur on the slopes. Glaciofluvial (gravels, sands) and aeolian (loess) deposits, related to Early Pleistocene glaciations are frequent in the northern part of the Sola catchment in the Carpathian Foothills (Nescieruk and Wójcik 2013).

\subsection{Tectonic setting}

SW to WSW-trending fold structures, WSWstriking numerous thrusts and reverse faults, together with transverse (i.e., NNW-striking) normal, obliqueslip and strike-slip faults predominate in the Sola catchment (Figure 5). The study area is composed of five nappes, which were overthrusted on each other from the south to the north. The Magura Nappe is the biggest and structurally the highest nappe and consists of four tectonic subunits limited by thrust zones. Inverse landscape, with anticlines producing low areas and synclines forming elevated areas, is characteristic in the area of this nappe. The Grybów and Dukla Nappes are formed as narrow zones of compressional duplexes overthrusted on top of the Silesian Nappe at the forehead of the Magura Nappe. Silesian Nappe consists of two subsidiary folded subunits divided by thrust zones. Formations of this nappe form three distinct monoclinal blocks, clearly seen in the morphology. Two of them are elevated and build mountain ranges, whereas, the third one is lowered and forms the north-western part of the Żywiec Basin. The WSW- to SW-trending fold structures (i.e., parallel to the strike of thrusts and reverse faults) play only a subordinate role here. Subsilesian Nappe is strongly tectonically disrupted and composed of thrust-faulted folds. Rock formations of the Subsilesian, Dukla and Grybów Nappes show a general structure of a mega-breccia (e.g., Książkiewicz 1977; Oszczypko 2004; Oszczypko et al. 2008; Nescieruk and Wójcik 2013; Ryłko and Paul 2013; Detailed Geological Map of Poland 2019). Breakout measurements suggest the NNE-SSW direction of the maximum horizontal stress $\left(S_{\mathrm{Hmax}}\right)$ in the nappes of the Outer Carpathians, rotated to NESW in the eastern part (e.g., Jarosiński 1998, 2005, 2006; Figure 4A).

\section{Materials and Methods}

For landscape analysis of the Sola catchment, we used a 25 m resolution Digital Terrain Elevation Data Level 2 (DTED-2, 2004), acquired from the Military Centre of Geodesy and Remote Sensing of Polish Army. DTED-2 model was prepared in the process of vectorization of contour lines, characteristic points, and skeletal lines from topographic maps on a scale of 1:50 o0o (Czajka 2009). Its horizontal accuracy reaches $16 \mathrm{~m}$ and vertical - 2-7 m (Kubiak and Stach 2013). For cartographic analysis and the calculation of morphometric indices, we used ArcGIS 10.7.1 (ESRI 2018) and QGIS 3.8 (QGIS Development Team 2019). For statistical analysis, we used the GeoRose software (Yong Technology Inc. 2014). We used precipitation data obtained from the Institute of Meteorology and Water Management - National Research Institute (IMWM - NRI 2020). Calculation of mean annual precipitation was performed for 17 stations for the period 1950-2019 using Python programming language (Van Rossum and Drake 2009). Data were interpolated by applying the ordinary kriging method.

Limits of the Sola River catchment were delineated using hydrological tools in the ArcGIS software based on the digital elevation model. A similar approach was used to delineate the boundaries of 47 sub-catchments of the Sola River's main tributaries. Four geomorphometric 

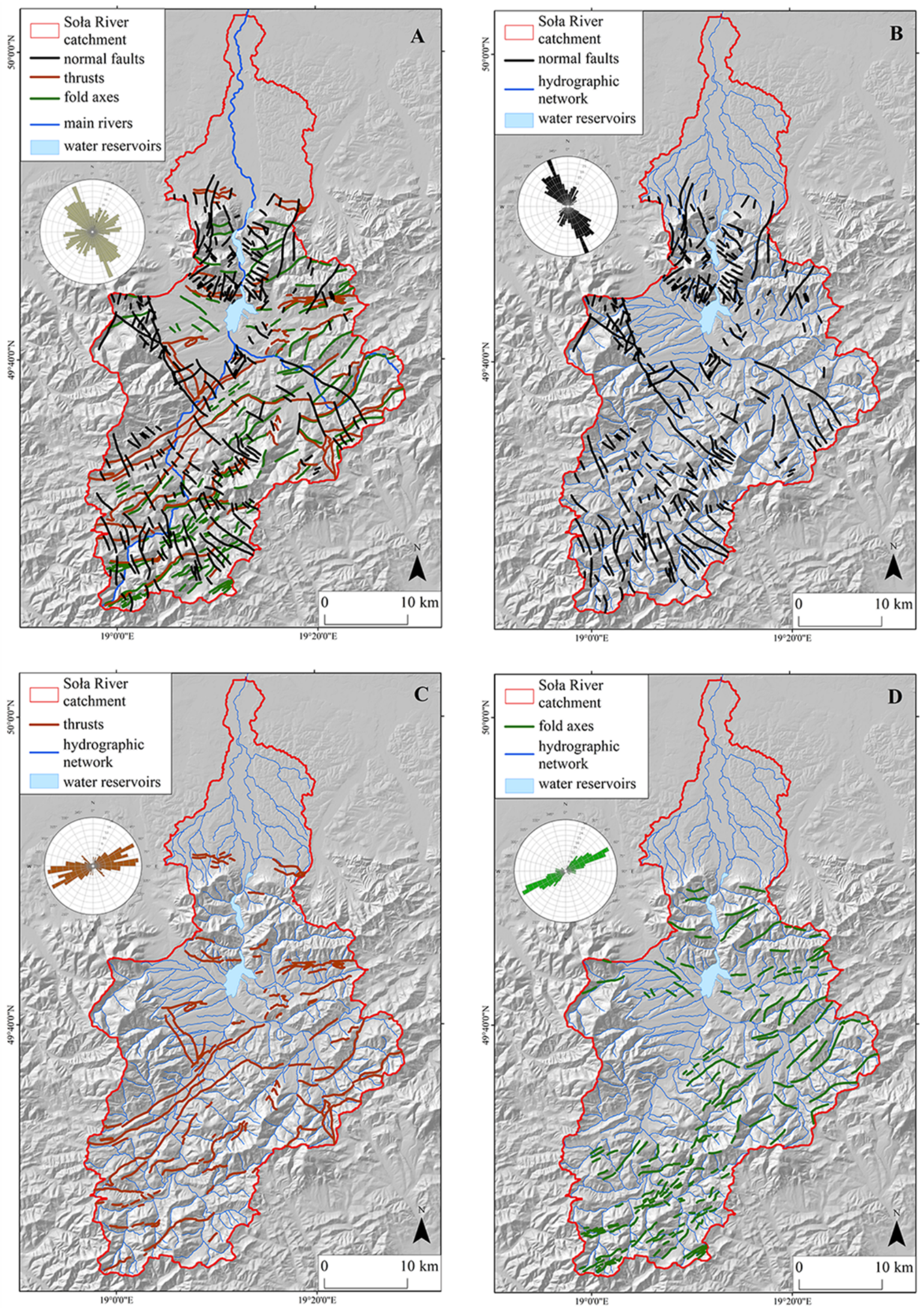

Figure 5 A -Spatial distribution and rose diagrams of tectonic structures in the Sola River catchment (according toDetailed Geological Map of Poland 2019) divided into: normal faults (B), reverse faults, and thrusts (C), and fold axes (D). Rose diagram in Figure $5 \mathrm{~A}$ shows the distribution of strikes of the normal faults and thrusts. 
Table 1 Geomorphometric indices calculated for 47 catchments located within the study area.

\begin{tabular}{|c|c|c|c|}
\hline Index name & Definition & Equation & Interpretation \\
\hline $\begin{array}{l}\text { Relief } \\
\text { ratio }\end{array}$ & $\begin{array}{l}\text { The ratio of maximal difference of height } \\
\text { in the catchment to its length (Strahler } \\
\text { 1964) }\end{array}$ & $=\frac{H_{\max }-H_{\min }}{\mathrm{L}}$ & $\begin{array}{l}\text { High } R_{\mathrm{h}} \text { values indicate a high medium slope } \\
\text { in a catchment and suggest a presence of high } \\
\text { relative uplift (Różycka and Migoń 2017) }\end{array}$ \\
\hline $\begin{array}{l}\text { Circulatory } \\
\text { ratio }\end{array}$ & $\begin{array}{l}\text { Compares the area of a catchment with } \\
\text { an area of a circle, which has a perimeter } \\
\text { equal to a perimeter of the catchment } \\
\text { (Miller 1953) }\end{array}$ & $R_{k}=\frac{4 \pi A}{P^{2}}$ & $\begin{array}{l}\text { High } R_{\mathrm{k}} \text { values suggest the more circular } \\
\text { shape of a catchment, i.e. shapes similar to } \\
\text { circle occur in tectonically stable areas } \\
\text { (Miller 1953) }\end{array}$ \\
\hline $\begin{array}{l}\text { Elongation } \\
\text { ratio }\end{array}$ & $\begin{array}{l}\text { The ratio of a diameter of a circle, which } \\
\text { area is equal to an area of a catchment, } \\
\text { to the maximal length of a catchment } \\
\text { (Eagleson 1970) }\end{array}$ & $R_{e}=\frac{2 \sqrt{\frac{A}{\pi}}}{L}$ & $\begin{array}{l}R \text { e values vary from o to } 1 \text {. Values close to } \\
\text { o indicate highly elongated catchment } \\
\text { suggesting increased tectonic activity (Bull } \\
\text { and McFadden 1977) }\end{array}$ \\
\hline $\begin{array}{l}\text { Hypsometric } \\
\text { Integral }\end{array}$ & $\begin{array}{l}\text { The ratio of a difference between medium } \\
\text { and minimal height to the difference of } \\
\text { minimal and maximal height in a } \\
\text { catchment (Pike and Wilson 1971) }\end{array}$ & $\begin{array}{l}\text { HI } \\
=\frac{H_{\text {avg }}-H_{\text {min }}}{H_{\text {max }}-H_{\min }}\end{array}$ & $\begin{array}{l}\text { The higher HI values, the higher intensity } \\
\text { of ongoing erosional processes in the } \\
\text { catchment. High } H I \text { values occur mainly in } \\
\text { tectonically active areas (Panek 2004) }\end{array}$ \\
\hline
\end{tabular}

indices related to catchment shape and relative relief, i.e. relief ratio $\left(R_{\mathrm{h}}\right)$, circulatory ratio $\left(R_{\mathrm{k}}\right)$, elongation ratio $\left(R_{\mathrm{e}}\right)$, and hypsometric integral (HI), were calculated for each of these, following procedures described in the literature (e.g., Miller 1953; Strahler 1964; Eagleson 1970; Bull and McFadden 1977; Pike and Wilson 1971; Keller and Pinter 2002; Pánek 2004; Anand and Pradhan 2019; Lama and Maiti 2019; Ghosh and Paul 2020) definitions, equations and interpretation of applied indices shown in Table 1). Minimum bulk erosion was calculated for the entire Sola catchment, as well as for the 47 analyzed tributary subcatchments. This index shows a minimum thickness of material eroded in each catchment (e.g., Giaconia et al. 2012; Gaidzik and RamírezHerrera 2017; Ramírez-Herrera et al. 2018). It was calculated as a difference between a theoretical pre-erosion surface and the DEM representing current relief, following the procedure by Brocklehurst and Whipple (2002).

Analyzed catchments were divided into two groups, using an area of $15 \mathrm{~km}^{2}$ as a threshold. Longitudinal river profiles were calculated for 24 rivers with catchment areas larger than the threshold, and for the Sola River itself. For each profile, a stream length-gradient index (SL) was calculated for points located in the middle of each 100-m segment of the river profile using the formula: $\mathrm{SL}=\Delta \mathrm{H} / \Delta \mathrm{L} \times \mathrm{L}$ (e.g., Hack 1973; Gaidzik and Ramírez-Herrera 2017). SL index shows the inclination of the longitudinal profile of the river for sections with a given length and enables accurate analysis of changes in the river gradient. The location of knickpoints was determined based on the river longitudinal profiles and SL-index charts. Knickpoint can be defined as a place in the river longitudinal profile, where a sudden increase in river bed gradient occurs caused by tectonic, lithological, or climatic factors (Galay 1983). Lineaments in the Sola catchment were interpreted based on the shaded relief and slope maps (Figure 1D). Directions of lineaments were summarized at rose diagrams using azimuth interval of 5 degrees.

\section{Results}

\subsection{Distribution of lineaments and faults}

Detailed analysis of the digital elevation model allowed us to detect lineaments that were categorized into four groups, i.e., lineaments related to 1) nappe structures, 2) strike-slip faults, 3) dip-slip faults, and 4) lineaments in the Quaternary deposits (Figure 6). Lineaments related to nappes, sub-parallel to these regional tectonic structures, show a relatively uniform distribution in the mountainous areas of the central and southern part of the studied catchment (Figure 6B). Their spatial orientation varies insignificantly ranging from WSW-ENE to SW-NE (Figure 6B), perpendicularly to the orientation of normal faults (see Figures 5B and 6B). These are generally relatively short features, usually not exceeding 5 $\mathrm{km}$. Straight segments of river valleys are commonly developed parallel to lineaments related to nappes (Figure $7 \mathrm{D}$ ). On the other hand, latitudinal lineaments that could be related to strike-slip faults are usually transverse or diagonal to hydrographic network, causing river deflections 

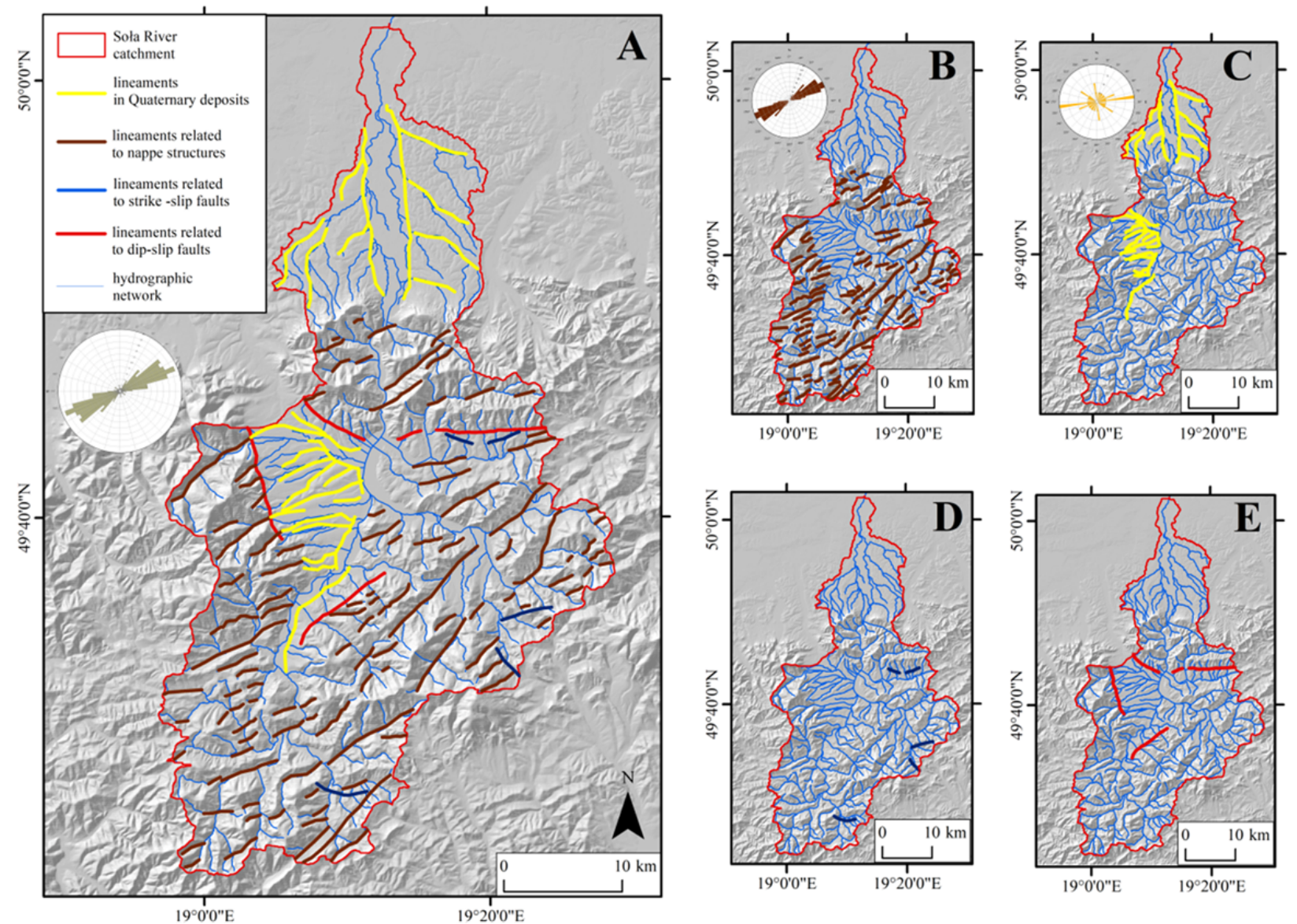

Figure 6 A -Spatial distribution and rose diagrams of lineaments in the Sola River catchment divided into: B lineaments related to nappe structures, $\mathrm{C}$ - lineaments in the Quaternary deposits, D - lineaments related to strikeslip faults, E - lineaments related to dip-slip faults.

or offsets (Figures 6D and $7 \mathrm{~B}$ ). Lineaments related to dip-slip faults were defined based on the triangular facets distribution, i.e. limiting the Żywiec Basin (Figures 2B, 6E, and 7C). The last group of lineaments was distinguished based on the youngest deposits (i.e., Quaternary river terraces), which these features crosscut. These predominantly longitudinal features were observed in basins in the central part of the Sola catchment and foothills located in the northern section (Figure 6C). Their spatial orientation shows a clear correlation with the river network in the Żywiec Basin and mountain foothills (Figures $3 \mathrm{~A}$ and 6C). It also corresponds to thrusts, and reverse faults, which might suggest that these structures could have been reactivated in the Quaternary (Figures 5 and 6C).

\subsection{Geomorphometric indices for catchments}

The selected 47 sub-catchments within the study area (Figure 8) present high variability in values of their geomorphometric parameters (see Tables 2 and 3). The smallest sub-catchments cover an area of $<5 \mathrm{~km}^{2}$ (Pisarzówka - 3.44, Przyborowiec - 3.51, Trzebinka - 4.52, Mała Puszcza - 4.9), whereas, the largest $>50 \mathrm{~km}^{2}$ (Łękawka - 55.2, Żylica - 52.95) (Table 2). The average area equals $18.9 \mathrm{~km}^{2}$ (Table 3). The elevation changes significantly from $<300 \mathrm{~m}$ a.s.l. (Żarnówka Mała, Domaczka) to > $1500 \mathrm{~m}$ a.s.l. (Glinne), with an average of $660 \mathrm{~m}$ a.s.l. (Tables 2 and 3).

Values of relief ratio $\left(R_{\mathrm{h}}\right)$ vary in a range between 41.72 and $167.7 \mathrm{~m}$, with an average of c. 90 $\mathrm{m}$ (see Tables 4 and 5). Most of the studied catchments $(>30)$ show a moderate or low relief ratio, i.e., $<100 \mathrm{~m}$. The highest values were computed for relatively small catchments located adjacent to the Soła Gorge (Żarnówka Mała 167.70, Mała Puszcza - 148.35), and the ones in highly elevated mountain ranges (Glinne - 136.51, 

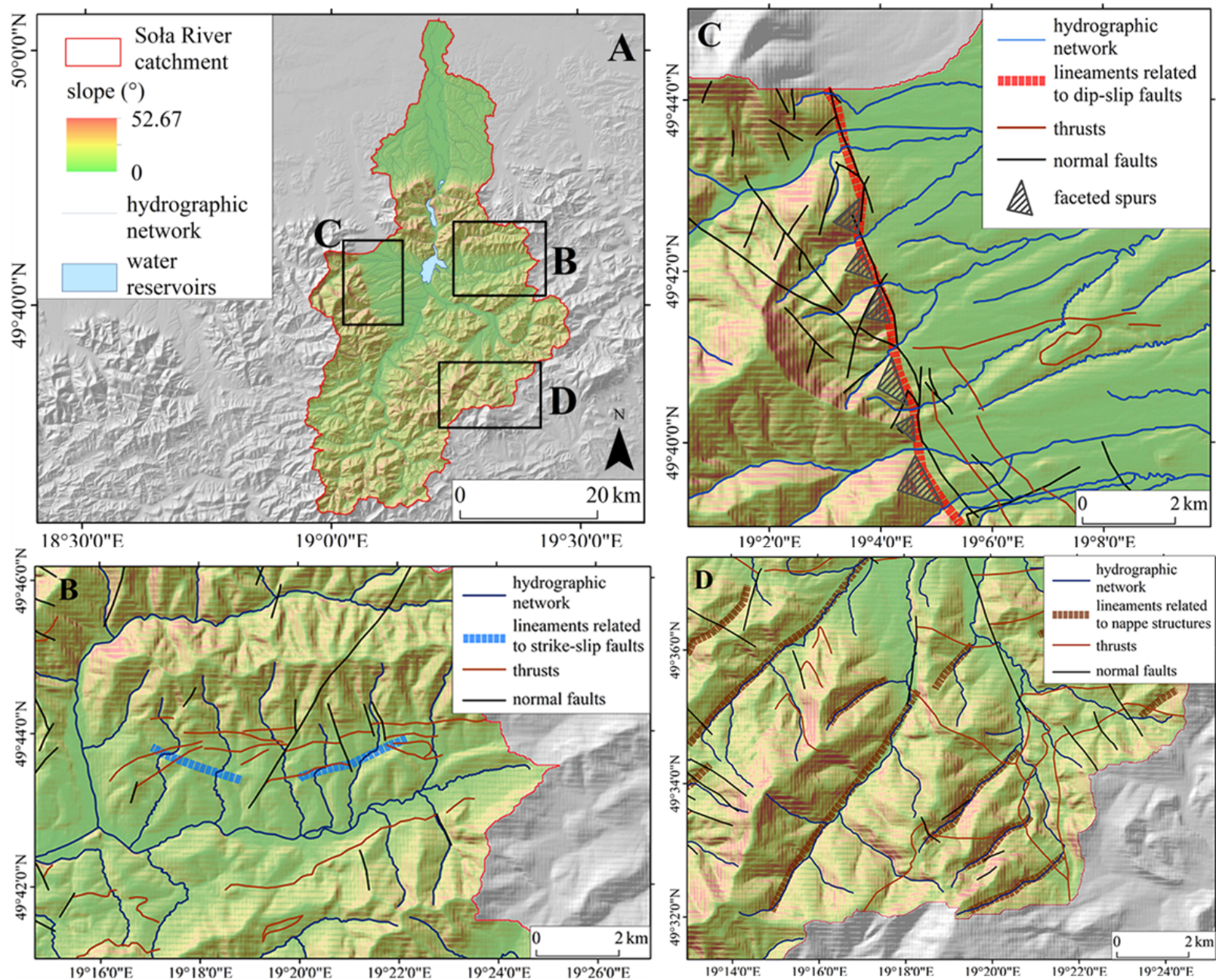

Figure 7 Relations between hydrographic network, lineaments, and faults: A -location of detailed maps shown in Figure 7B-D; B - river deflections probably related to a strike-slip fault; C - faceted spurs at the border of mountain massif related to normal faults; D - straight segment of rivers developed parallel to lineaments related to nappe structures.

Janoszka - 109.07) (Table 4, Figures 8 and 9A). Low values are observed in catchments located partially on mountain foothills (Pisarzówka - 57.37, Domaczka - 88.60), and in the area of the Żywiec Basin (Moszczanica - 47.55, Kalna - 56.93) (Table 4, Figures 8 and 9A). Also, catchments located in the NE (Łękawka - 44.86, Kocierzanka - 46.36), and SW (Słanica - 57.14, Rycerski Potok - 62.95) parts of the study area show low values of this ratio (Table 4, Figs. 8 and 9A). It appears to be related to both, relatively low values of maximum height in each catchment, and their high length.

Circulatory ratio $\left(R_{\mathrm{k}}\right)$ values calculated for 47 sub-catchments in the study area vary moderately from 0.19 to 0.46 (see Tables 4 and 5), suggesting predominance of non-circular shapes of these features. The highest values of this ratio associated with catchments of nearly circular shape are located in the surrounding of the Sola Gorge (Żarnówka Duża - 0.45, Roztoka - 0.41), and in the central-eastern and central-western (Glinne 0.4, Bystra I - 0.4) parts of the study area, whereas these with the lowest $R_{\mathrm{k}}$ values occupy an area adjacent to the Żywiec Basin (Leśnianka - 0.23, Przybędza - 0.20) (Table 4, Figures 8 and 9B).

Elongation ratio $\left(R_{\mathrm{e}}\right)$ values for 47 studied catchments range between 0.4 and 0.94 (see Tables 4 and 5). The highest values are observed in catchments located in the NW (Wieśnik- 0.94), SW (Nieledwianka - 0.84, Rycerski Potok - 0.73), and E (Pewlica - 0.76, Łękawka - 0.73) parts of the Sola River catchment, as well as in the area adjacent to the Sola Gorge (Isepnica - 0.74, Mała Puszcza - 0.71) (Table 4, Figures 8 and 9C). The lowest $R_{\mathrm{e}}$ values occur in catchments partially located within the Żywiec Basin and foothills 


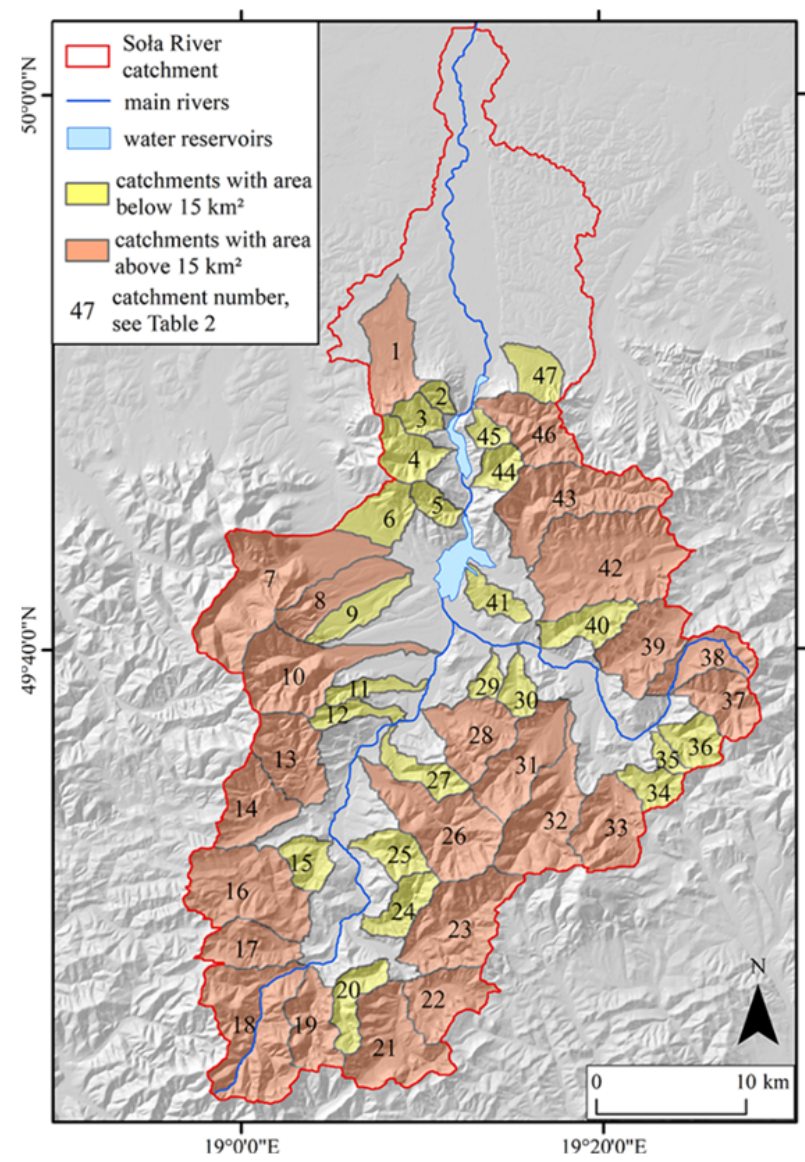

Figure 847 distinguished sub-catchments within the Sola River catchment used for the calculation of the geomorphometric indices. Numbering as in Tables 2 and 4 .

Table 3 Statistical characteristics of geomorphometric parameters of 47 sub-catchments

\begin{tabular}{|c|c|c|c|c|c|c|c|}
\hline Grou & ristics & $\begin{array}{l}A \\
\mathrm{~km}^{2}\end{array}$ & $\begin{array}{l}P \\
\mathrm{~km}\end{array}$ & $\begin{array}{l}L \\
\mathrm{~km}\end{array}$ & $H_{\text {min }}$ & $H_{\max }$ & $H_{\text {avg }}$ \\
\hline \multirow{3}{*}{$\begin{array}{l}\text { All } \\
\text { catchments }\end{array}$} & & & 9 & 3.0 & & & \\
\hline & & & & 14.7 & & & \\
\hline & & & & 7.3 & & & \\
\hline \multirow{3}{*}{$\begin{array}{l}\text { Catchments } \\
\text { witharea } \\
>15 \mathrm{~km}^{2}\end{array}$} & & & 22 & 6.3 & & & \\
\hline & 4 & & 49 & 14.7 & 5 & & \\
\hline & & 28.6 & 3 & 9.2 & & & \\
\hline \multirow{3}{*}{$\begin{array}{l}\text { Catchments } \\
\text { witharea } \\
<15 \mathrm{~km}^{2}\end{array}$} & & & & 3.0 & 28 & & \\
\hline & & 13. & 24 & 8.6 & 53 & & \\
\hline & Average & 8.7 & 17.9 & $5 \cdot 3$ & 394 & 90 & 598 \\
\hline
\end{tabular}

Note: $A$, Area; $P$, Perimeter; $L$, Length of catchment; $H_{\min }$, Minimum height; $H_{\max }$, Maximum height; $H_{\text {avg}}$, Average height.

(Leśnianka - 0.49, Przybędza - 0.44) (Table 4, Figures 8 and 9C). Relatively low values are noted also for catchments situated in the centralsouthern part of the study area (Cięcinka - 0.59, Sopotnia Wielka - o.52) (Table 4, Figures 8 and
Table 2 Values of geomorphometric parameters used for calculation of geomorphometric indices for $47 \mathrm{sub}-$ catchments (for location see Figure 8).

\begin{tabular}{|c|c|c|c|c|c|c|c|}
\hline & Name of the & $A$ & $P$ & $L$ & $H_{\min }$ & $H_{\max }$ & $H_{\text {avg }}$ \\
\hline No & & $\mathrm{km}^{2}$ & $\mathrm{~km}$ & $\mathrm{~km}$ & m a.s.l. & m a.s.l. & ma.s \\
\hline 1 & Pisarzówka & 22.98 & 31.38 & 9.50 & 286 & 831 & 417.6 \\
\hline 2 & Żarnówka Mała & 3.44 & 9.73 & 3.01 & 321 & 826 & 578.1 \\
\hline 3 & Żarnón & 6.52 & 13.45 & 3.86 & 319 & 831 & 568.0 \\
\hline 4 & Ponik & 12.68 & 20.73 & 5.57 & 320 & 929 & 599.7 \\
\hline 5 & Rozt & 6.02 & 13.60 & 4.02 & 329 & 928 & 561.9 \\
\hline 6 & & 6.49 & 20.89 & 7.14 & 366 & 948 & 553.2 \\
\hline 7 & & 2.95 & 49.62 & 14.71 & 371 & 1254 & 693.4 \\
\hline 8 & & .57 & 30.11 & 9.89 & 352 & 1253 & 531.1 \\
\hline & & & 24.55 & 8.64 & 351 & 843 & 456.0 \\
\hline 10 & & 4.26 & 43.25 & 13.43 & 355 & 251 & 778.5 \\
\hline 11 & & & 20.78 & 4.45 & 371 & 14 & 494.1 \\
\hline 2 & & 84 & 20 & 6.70 & 385 & & 680.7 \\
\hline 3 & & & & 7.28 & 480 & & 81.4 \\
\hline 4 & & 3 & & 6.43 & 480 & & 01.1 \\
\hline 5 & & & & 4.13 & 44 & & 12.8 \\
\hline 16 & Cze & 32 & 36. & 9.59 & 533 & & 73.4 \\
\hline 7 & & & & $7 \cdot 32$ & 53 & & 6.3 \\
\hline 8 & & & 44. & 10.72 & & 233 & $47 \cdot 7$ \\
\hline 9 & & .10 & 26.5 & 7.16 & 558 & 219 & 47.4 \\
\hline 0 & & .18 & 24.0 & 6.99 & 553 & 192 & 47.7 \\
\hline 1 & C & 0.98 & & 8.27 & 580 & 217 & 41.1 \\
\hline 22 & Glin & .24 & 25.62 & 6.57 & 579 & 661 & 94.7 \\
\hline 3 & & 4.41 & 34.54 & 10.29 & & 322 & 54.4 \\
\hline & & 40 & 21.09 & 6.26 & 493 & 41 & 737.0 \\
\hline 5 & & .44 & 19.00 & 5.99 & 454 & 240 & 740.2 \\
\hline 6 & Żab & 36.39 & 38.84 & 11.61 & 410 & 1361 & 781.7 \\
\hline 7 & & 0.62 & 24.20 & 6.73 & 390 & & 612.1 \\
\hline 8 & & 2.21 & 27.76 & 6.73 & 378 & & 611.2 \\
\hline 9 & & .52 & 13.04 & 3.79 & 366 & 85 & 485.5 \\
\hline o & Prz & & & 4.88 & 378 & & 49.8 \\
\hline 1 & & .75 & 31.85 & 9.38 & 467 & 348 & 713.7 \\
\hline 2 & & & 2.11 & 12.42 & 468 & 385 & 24.7 \\
\hline & Glin & 3.46 & $25 \cdot 32$ & 7.03 & 543 & 503 & 859.8 \\
\hline 4 & & 8.59 & 17.27 & 4.67 & & & 719.4 \\
\hline 5 & Prz & & 11.77 & 3.77 & 50 & 050 & 722.9 \\
\hline 6 & & & 17.78 & 4.90 & 518 & & 756.5 \\
\hline & & & 22.72 & 6.28 & 563 & & 848.6 \\
\hline 38 & & 16.28 & 27.00 & 7.94 & 56 & & 762.6 \\
\hline 9 & & 15 & & 7.28 & & & 589.0 \\
\hline & & & & 7.09 & 38 & & 556.3 \\
\hline 41 & & 8.26 & 18.80 & 5.64 & 34 & & $403 \cdot 3$ \\
\hline & & & 43.81 & 11.48 & 365 & & \\
\hline & & & 44.73 & 11.97 & 366 & & \\
\hline & & 1.00 & 14.67 & 4.18 & 319 & & 589.0 \\
\hline & & 4.90 & 12.43 & 3.50 & 305 & & 512.0 \\
\hline & & 9.99 & 27.76 & 8.41 & 30 & 002 & 573.9 \\
\hline 7 & Domaczka & 10.78 & 17.42 & $5 \cdot 37$ & 289 & 705 & $42 / .0$ \\
\hline
\end{tabular}

Note: $A$, Area; $P$, Perimeter; $L$, Length of catchment; $H_{\min }$, Minimum height; $H_{\max }$, Maximum height; $H_{\text {avg }}$, Average height.

9C). The values of the hypsometric integral (HI) range from 0.2 to 0.51 (see Tables 4 and 5), with most catchments placed within a narrow range of 0.35-0.45. The occurrence of the highest values of this index is associated with the presence of deep- 
incised valleys (e.g., Żarnówka Mała - 0.51, Wielka Puszcza - 0.47), and highly elevated massifs, i.e., Skrzyczne Massif (Leśnianka - 0.47), Romanka Massif (Sopotnia Wielka - 0.5), Muńcuł Massif (Danielka - 0.46) (Table 4, Figures 8 and 9D). Relatively high values are noted also for catchments located in the W, S, and SE parts of the Sola River catchment (Bystra I - 0.41, Rycerki 0.44, Przyborowiec - 0.40) (Table 4, Figures 8 and 9D). The lowest HI values are usually computed for areas of low elevation (e.g., Pisarzówka - 0.24, Moszczanica- 0.23, Łękawka- 0.3, Janoszka- 0.32) (Table 4, Figures 8 and 9D).

\subsection{Longitudinal profiles, stream length- gradient index and knickpoints}

Mostof the longitudinal river profiles generated for rivers with catchment areas $>15 \mathrm{~km}^{2}$ presents close to equilibrium concave shape (e.g., Janoszka, Pisarzówka, Sopotnia Wielka) (Figure 10). Similar concave pattern, with well-marked knickpoints, is also demonstrated in the Sola and Koszarawa profiles, i.e., the main river and its principal longest tributary (Figure 10). Generally, the shortest rivers show the largest disturbances of profile concavity (e.g., Bystra III, Glinka, Pewlica), however, some larger rivers also present transient profiles (e.g., Kocierzanka, Czerna) (Figures 8 and 10).

Stream length-gradient index values vary between 140 and 250 for rivers flowing through areas of relatively low local relief (e.g., Czerna, Słanica), and reach up to $450-500$ for rivers draining the highly elevated areas (e.g., Rycerski Potok, Sopotnia Wielka, Glinne) (Figure 10). The highest SL values obtained for Koszarawa (1000) and Soła (6000) rivers are probably related to the significant length of these two rivers. In general, high SL values correspond well with considerable breaks in river longitudinal profiles, corroborating their location. In total 53 knickpoints were identified along the Sola River and its 24 main tributaries, based on the river longitudinal profiles and variations in SL index (Figure 11). The number of distinguished knickpoints varies from o (Kalonka and Pisarzówka) to 5 (Glinka) (Figure 10). Detected knickpoints appear to cluster in two main elevation ranges: 1) $570-620 \mathrm{~m}$ a.s.l. (15 knickpoints), and 2) $620-$ $670 \mathrm{~m}$ a.s.l. (7 knickpoints) (Figure 11A). 4 knickpoints located in the $\mathrm{S}$ and $\mathrm{W}$ part of the
Table 4 Values of four geomorphometric indices calculated for 47 sub-catchments (for location see Figure 8).

\begin{tabular}{|c|c|c|c|c|c|}
\hline No & Name of the catchment & $R_{\mathrm{h}}$ & $R_{\mathrm{k}}$ & $R_{\mathrm{e}}$ & HI \\
\hline 1 & Pisarzówka & 57.37 & 0.29 & 0.57 & 0.24 \\
\hline 2 & Żarnówka Mała & 167.70 & 0.46 & 0.69 & 0.51 \\
\hline 3 & Żarnówka Duża & 132.56 & 0.45 & 0.75 & 0.49 \\
\hline 4 & Ponikiew & 109.27 & 0.37 & 0.72 & 0.46 \\
\hline 5 & Roztoka & 148.89 & 0.41 & 0.69 & 0.39 \\
\hline 6 & Wiśnik & 81.49 & 0.19 & 0.40 & 0.32 \\
\hline 7 & Żylica & 60.03 & 0.27 & 0.56 & 0.37 \\
\hline 8 & Kalonka & 91.12 & 0.26 & 0.49 & 0.20 \\
\hline 9 & Kalna & 56.93 & 0.24 & 0.44 & 0.21 \\
\hline 10 & Leśnianka & 66.73 & 0.23 & 0.49 & 0.47 \\
\hline 11 & Wie & 122.03 & 0.40 & 0.94 & 0.23 \\
\hline 12 & Przyl & 96.72 & 0.20 & 0.44 & 0.46 \\
\hline 13 & Byst & 100.35 & 0.40 & 0.73 & 0.41 \\
\hline 14 & Jan & 109.07 & 0.35 & 0.79 & 0.32 \\
\hline 15 & Nieledwianka & 90.34 & 0.42 & 0.84 & 0.44 \\
\hline 16 & Czer & 41.72 & 0.36 & 0.73 & 0.35 \\
\hline 17 & Słan & 57.14 & 0.38 & 0.61 & 0.39 \\
\hline 18 & ski Potok & 62.95 & 0.30 & 0.73 & 0.43 \\
\hline 19 & Ryce & 92.31 & 0.32 & 0.67 & 0.44 \\
\hline 20 & Dani & 91.45 & 0.26 & 0.56 & 0.46 \\
\hline 21 & Cicha & 76.99 & 0.31 & 0.76 & 0.41 \\
\hline 22 & Glinl & 73.32 & 0.37 & 0.75 & 0.45 \\
\hline 23 & Bys & 74.81 & 0.36 & 0.64 & 0.39 \\
\hline 24 & Nick & 103.44 & 0.32 & 0.61 & 0.38 \\
\hline 25 & Salar & 97.88 & 0.36 & 0.61 & 0.49 \\
\hline 26 & zzanka & 81.90 & 0.30 & 0.59 & 0.39 \\
\hline 27 & Cięcinka & 82.03 & 0.23 & 0.55 & 0.40 \\
\hline 28 & Jusz & 83.61 & 0.36 & 0.79 & 0.41 \\
\hline 29 & Trze & 84.10 & 0.33 & 0.63 & 0.37 \\
\hline 30 & Prz & 77.59 & 0.37 & 0.62 & 0.45 \\
\hline 31 & Sop & 93.97 & 0.32 & 0.61 & 0.28 \\
\hline 32 & nia Wielka & 73.86 & 0.23 & 0.52 & 0.50 \\
\hline 33 & Glin & 136.51 & 0.46 & 0.78 & 0.33 \\
\hline 34 & $\mathrm{Krz}$ & $105 \cdot 30$ & 0.36 & 0.71 & 0.36 \\
\hline 35 & owiec & 143.95 & 0.32 & 0.56 & 0.40 \\
\hline 36 & Przy & 112.69 & 0.43 & 0.76 & 0.43 \\
\hline 37 & Bys & 96.12 & 0.40 & 0.73 & 0.47 \\
\hline 38 & Górna Koszarawa & 69.00 & 0.28 & 0.57 & 0.37 \\
\hline 39 & Pew] & 60.74 & 0.35 & 0.76 & 0.37 \\
\hline 40 & Pewlica II & 52.88 & 0.29 & 0.57 & 0.45 \\
\hline 41 & Moszczanica & 47.55 & 0.29 & 0.58 & 0.23 \\
\hline 42 & Łękawka & 44.86 & 0.36 & 0.73 & 0.30 \\
\hline 43 & Kocierzanka & 46.36 & 0.24 & 0.59 & 0.48 \\
\hline 44 & Isepnica & 126.68 & 0.44 & 0.74 & 0.51 \\
\hline 45 & Mała Puszcza & 148.35 & 0.40 & 0.71 & 0.40 \\
\hline 46 & Wielka Puszcza & 69.09 & 0.33 & 0.60 & 0.47 \\
\hline 47 & Domaczka & 88.56 & 0.45 & 0.69 & 0.29 \\
\hline
\end{tabular}

Table 5 Statistical characteristics of geomorphometric indices calculated for 47 sub-catchments in the Sola River catchment.

\begin{tabular}{|l|l|l|l|l|}
\hline $\begin{array}{l}\text { Statistical } \\
\text { characteristics }\end{array}$ & $R_{\mathrm{h}}$ & $R_{\mathrm{k}}$ & $R_{\mathrm{e}}$ & HI \\
\hline Minimum & 41.72 & 0.19 & 0.40 & 0.20 \\
\hline Maximum & 167.7 & 0.46 & 0.94 & 0.51 \\
\hline Average & 89.11 & 0.34 & 0.65 & 0.39 \\
\hline
\end{tabular}

Note: relief ratio $\left(R_{\mathrm{h}}\right)$, circulatory ratio $\left(R_{\mathrm{k}}\right)$, elongation ratio $\left(R_{\mathrm{e}}\right)$, and hypsometric integral $(\mathrm{HI})$. 

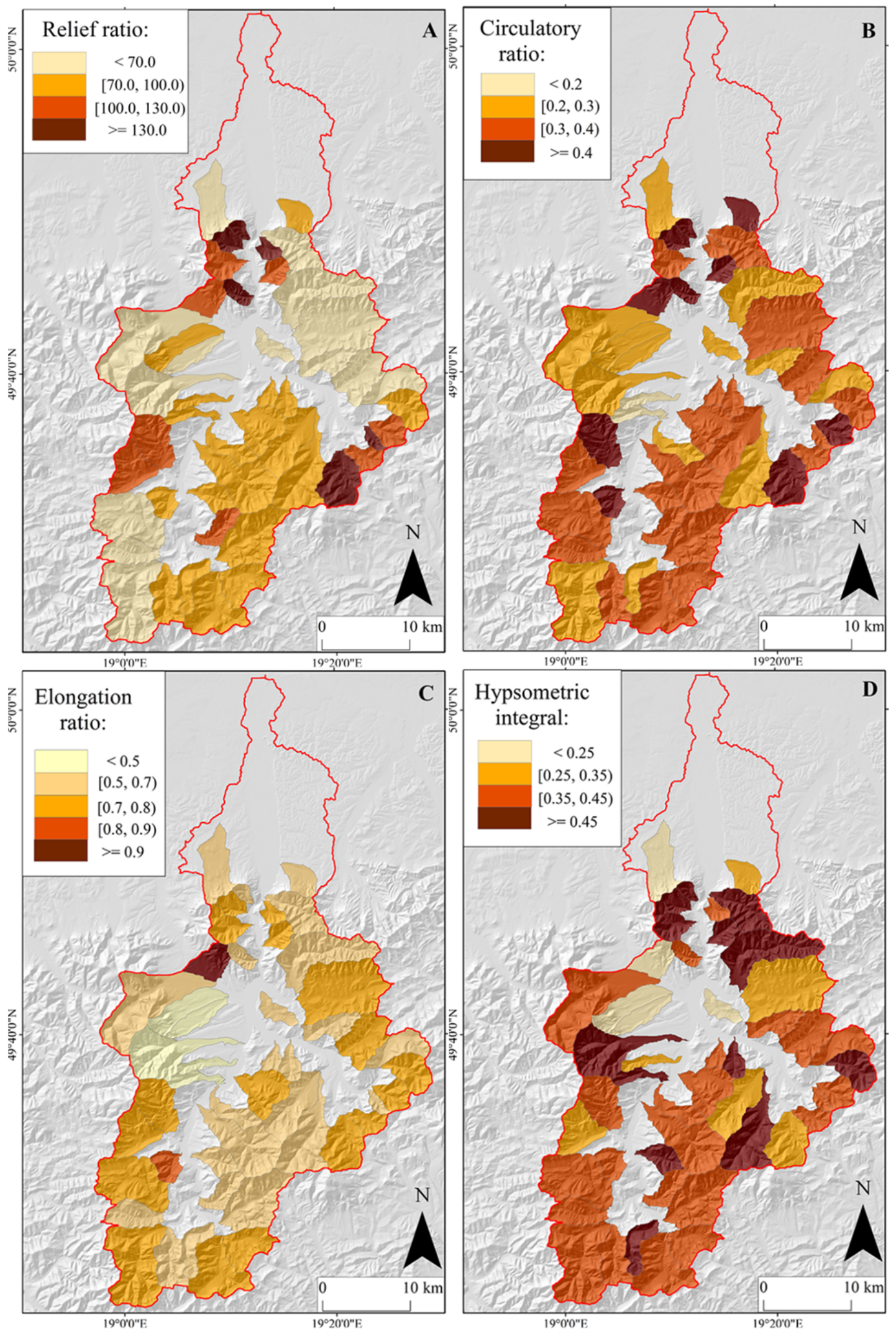

Figure 9 Spatial variation in values of relief ratio (A), circulatory ratio (B), elongation ratio (C), and hypsometric integral (D) calculated for 47 sub-catchments within the Sola River catchment. 

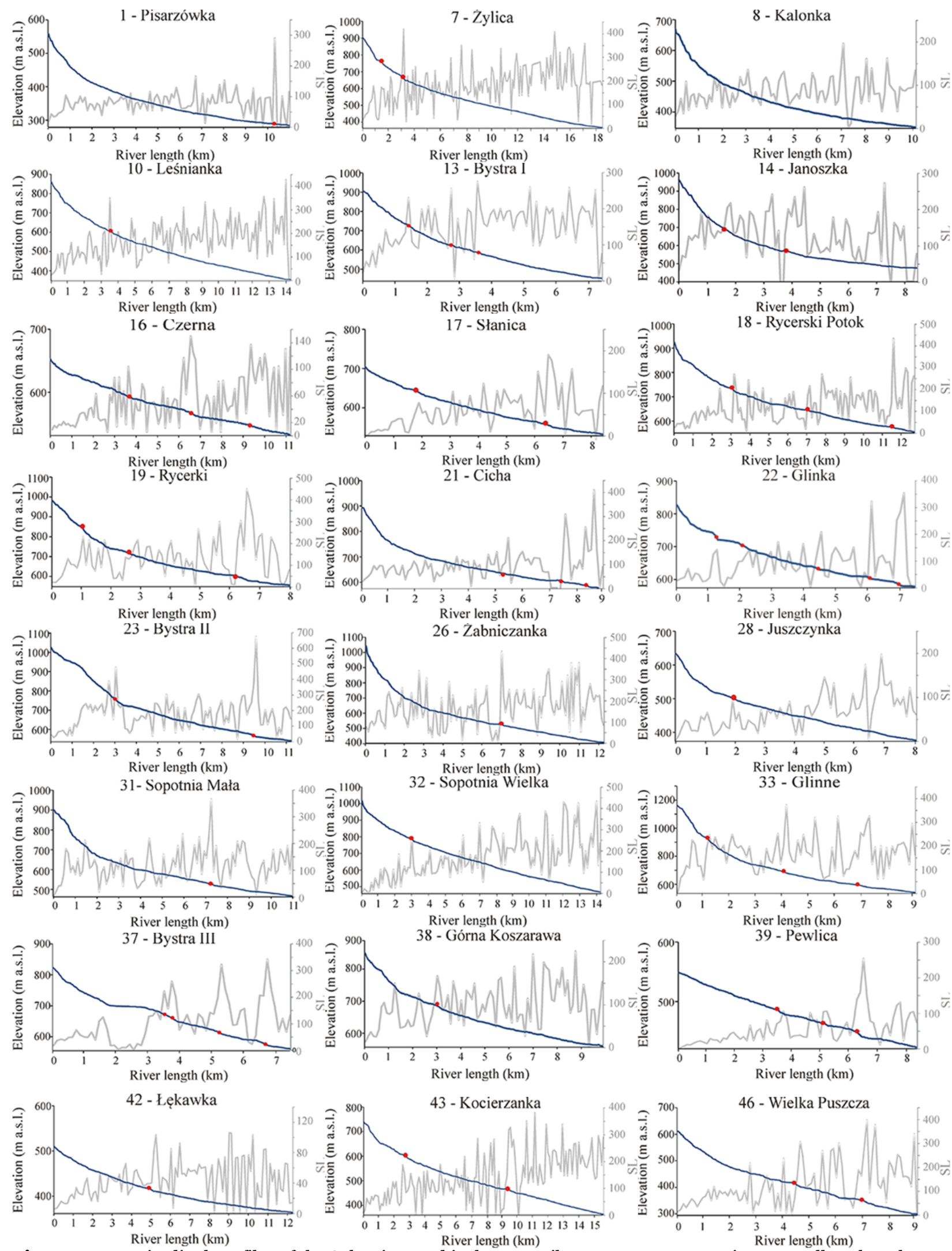

Figure 10 Longitudinal profiles of the Soła River and its longest tributary - Koszarawa River, as well as the other 24 main tributaries with area $>15 \mathrm{~km}^{2}$. Numbering as in Figure 8, and Tables 2 and 4. (-To be continued-) 
(-Continued-)
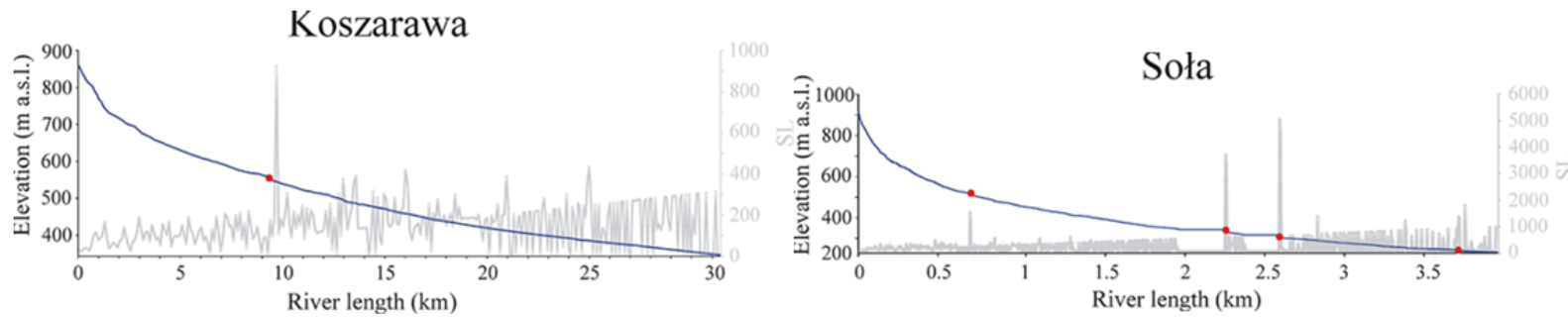

Figure 10 Longitudinal profiles of the Soła River and its longest tributary - Koszarawa River, as well as the other 24 main tributaries with area $>15 \mathrm{~km}^{2}$. Numbering as in Figure 8, and Tables 2 and 4.
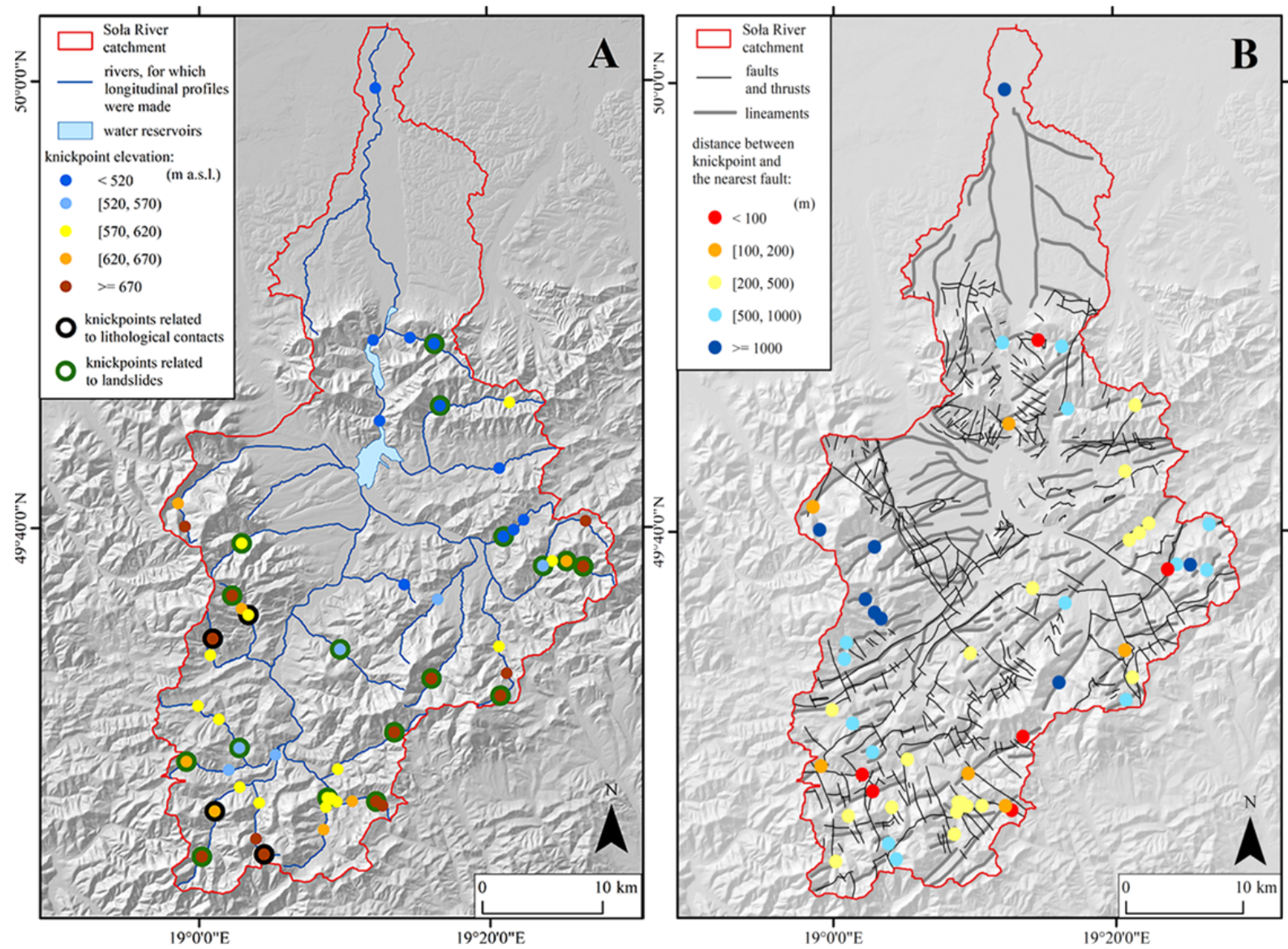

Figure 11 Spatial distribution of detected knickpoints in the Sola River catchment; A - knickpoints classified according to their elevation a.s.l.; B - knickpoints categorized based on their distance to the adjacent faults.

study area occur on the contact of resistant sandstones with more erodible shales (Figures 4 and 10A). A group of 18 knickpoints appears to be related to mass movement processes, as these are located adjacent to the landslide features reaching the valley floor (Figure 11A). Some of the knickpoints are associated with detected faults network, i.e., 12 knickpoints situated $<200 \mathrm{~m}$ to the nearest transverse or diagonal fault zone (e.g., Rycerski Potok, Glinka, Wielka Puszcza; Figure 11B). However, in most of the cases, the distance between knickpoint and the nearest fault exceeds
$500 \mathrm{~m}$ (Figure 11B). Two knickpoints located in the central part of the Sola River course refer to manmade water reservoirs and dams (Figures 10 and 11).

\subsection{Minimum bulk erosion}

Values of minimum bulk erosion calculated for the Sola River catchment vary significantly from 0 $\mathrm{m}$ on mountain ranges bordering the catchment limits to $>500 \mathrm{~m}$ in two areas characterized by a deeply incised principal river valley, i.e., 1) to the 

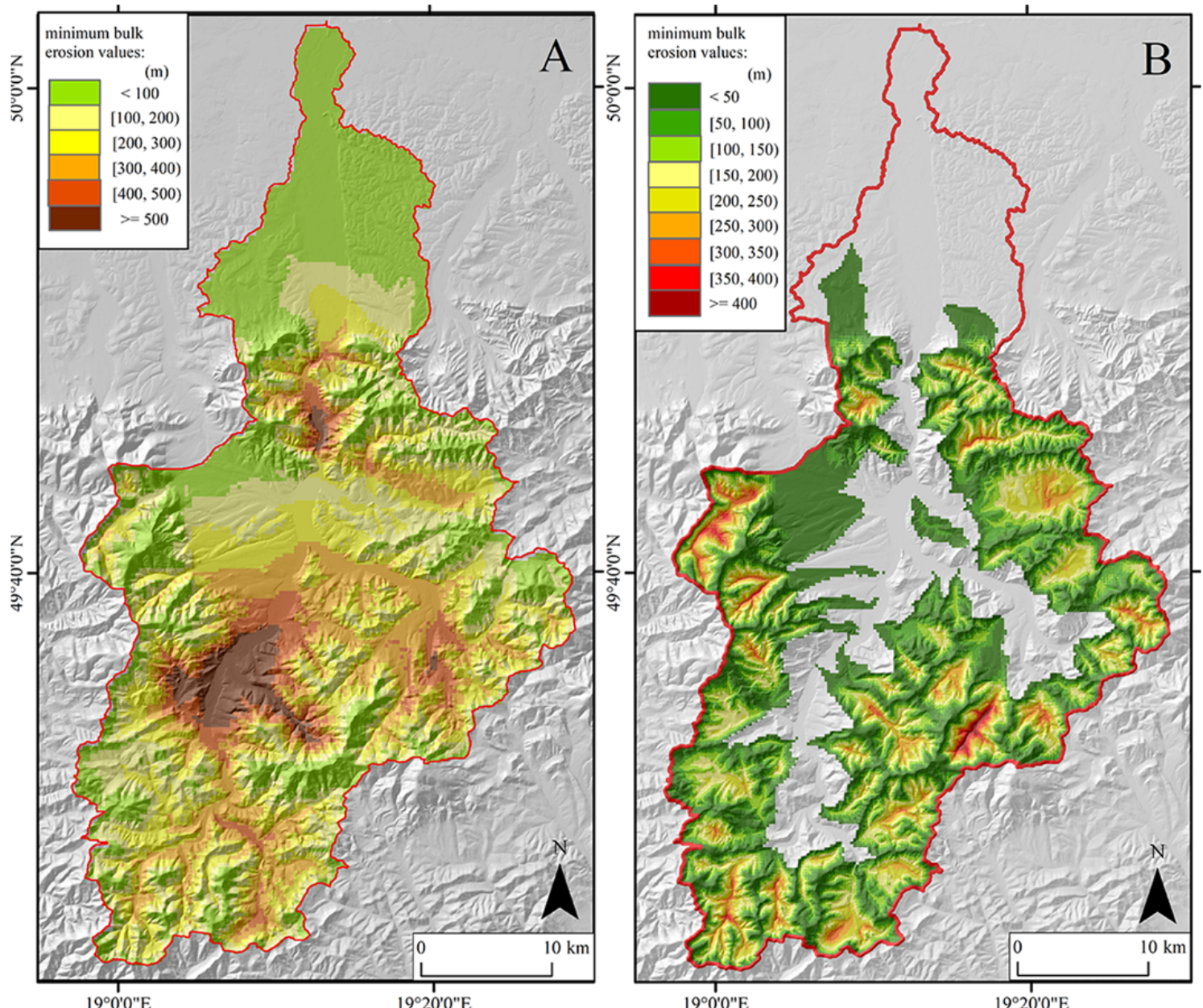

Figure 12 Spatial distribution of minimum bulk erosion calculated for the entire Soła River catchment (A) and for 47 catchments (B).

south of the Żywiec Basin, where the Sola River flows between highly elevated massifs of Beskid Śląski and Beskid Żywiecki Mts., and 2) the Sola Gorge, to the north of the Żywiec Basin (Figure $12 \mathrm{~A})$. Recorded low values $(<100 \mathrm{~m})$ mainly refer to the ridges and areas with low relative relief like basins and foothills, especially in the NW part of the Żywiec Basin and in the northern section of the study area (Figure 12A). In general, high values of this index are associated with deeply incised valleys bordered by high mountain ridges, while low values relate to wide, flat valleys surrounded by low ridges.

The minimum bulk erosion calculated for each of the 47 sub-catchments separately shows high values for catchments with rivers flowing in SWNE direction (Sopotnia Wielka 460, Żylica 400, Leśnianka 350), and in places of river confluences (e.g., in Rycerski Potok, Glinne, Bystra II catchments) (Figures 8 and 12B). Low values, on the other hand, refers to wide valleys (e.g., Czerna, Pewlica), those surrounded by low ridges (e.g., Janoszka, Górna Koszarawa) and the smallest subcatchments, as these present the lowest local relief (Roztoka 200, Nieledwianka 250) (Figures 8 and 12B).

\section{Discussion}

\subsection{Passive tectonic control on the relief development}

Results of our landscape analysis, including lineaments and faults detection and their spatial distribution analysis, together with geomorphometric and hydrographic network analysis, show the importance of inherited tectonic structures in relief development of the Sola River catchment. The main principle direction of river flow, i.e., towards the $\mathrm{NNE}$, in general, follows the topographic gradient 
of the Beskidy Mts. (Figure 3A). However, in some areas deviations from this general trend can be observed, especially in the southern and northern parts of the study area, caused by the influence of fault structures (Figures $5^{\mathrm{B}}$ and $\mathrm{C}$ ). These are usually normal or reverse faults, with occasional strike-slip structures. Large valleys commonly coincide with the traces of NW-striking normal faults (Figures $5 \mathrm{~B}$ and $7 \mathrm{D}$ ). Similarly-oriented fault structures were observed also bordering large depressions and basins, i.e., Żywiec Basin (Figures $2 \mathrm{~B}, 5 \mathrm{~B}$, and $7 \mathrm{C}$ ). The predominant direction of fault and lineaments structures related to nappes (i.e., WSW- to SW-striking; Figures $5 \mathrm{C}$ and $6 \mathrm{~B}$ ) corresponds with the trace of fold structures (Oszczypko et al. 2008; Ryłko and Paul 2013; Figure 5D) and is commonly used by the Sola River tributaries (Figures $3 \mathrm{~A}$ and $7 \mathrm{D}$ ). Most of the mountain ridges and lineaments in this area also follow this principle structural direction (Figures1D and 6). The location of the intra-mountainous depressions and basins is often conditioned by the presence of narrow nappe zones developed as strongly disrupted tectonic mélanges, with significant susceptibility to erosional processes, i.e.,the mélange outcrops of Grybów and Dukla Nappes (Figures 1C and 4B; see also Oszczypko 2004; Jankowski and Margielewski 2014).

\subsection{Geomorphometric indices}

Values of geomorphometric indices, i.e., relief ratio, circulatory ratio, elongation ratio, and hypsometric integral, calculated for 47 subcatchments show the significant variety, which does not correlate with changes in lithology or climate variations (Table 4 , and Figures $3 \mathrm{~B}, 4 \mathrm{~B}$ and 9). According to obtained values, the most elongated catchments with significant variability in local relief are located in the southern and eastern part of the study area (within the Beskid Żywiecki Mts.) and to the north of the Żywiec Basin, adjacent to the Sola Gorge (Figure 9). Previous studies proved that such catchments are indicative of high relative uplift rates (Table S1; e.g., Miller 1953; Bull and McFadden 1977; Schumm et al. 2000; Burbank and Anderson 2001; Keller and Pinter 2002; Ruszkiczay-Rüdiger et al. 2009; Pérez-Peña et al., 2010; Giaconia et al. 2012; Matoš et al. 2013; Różycka and Migoń, 2017; Gaidzik and
Ramírez-Herrera 2017; Ramírez-Herrera et al. 2018), also in areas of low tectonic activity (e.g.,Badura et al. 2003; Pánek 2004; Wołosiewicz 2018). For example, landscape analysis using similar geomorphometric indices suggested tectonic activity along the Sudetic Marginal Fault in the Sudetes (Badura et al. 2003). This conclusion was later corroborated by paleoseismological trenching (Štěpančíková et al. 2010), and geophysical studies (Štěpančíková et al. 2011). Moreover, detected areas of high relative rock uplift correspond to axes of neotectonic elevations delineated by Zuchiewicz (1998).

Spatial variations in the minimum bulk erosion in the Sola River catchment does not appear to be related to changes in lithological and climatic conditions (Figures 3B, 4B, and 12). Differences in lithology between areas of high and low values of minimum bulk erosion are not significant (compare Figures 4B and 12A). These variations are usually local and include only changes in proportions between sandstones and shales that cannot explain observed anomalies in this index. Also variations in climatic conditions are inconsiderable as the climate of the entire study area is similar and is conditioned mainly by the elevation a.s.l. Areas with high and low values of mean annual precipitation do not correlate with areas of maximum and minimum values of minimum bulk erosion (Figures $3 \mathrm{~B}$ and 12A). A similar lack of correlation between lithology, climate, and minimum bulk erosion values was observed by Giaconia et al. (2012), and by Gaidzik and Ramírez-Herrera (2017). Thus, recorded variations in the minimum bulk erosion may reflect changes in relative rock uplift. Both areas of high erosion, i.e., high relative rock uplift, 1) to the south of the Żywiec Basin, with deeply incised Soła River valley between highly elevated massifs of Beskid Śląski Mts. and Beskid Żywiecki Mts., and 2) the Sola Gorge, to the north of the Żywiec Basin (Figures 2A and 12A) correlate with mentioned earlier areas distinguished based on relief ratio, circulatory ratio, elongation ratio, and hypsometric integral, as well as zones of anomalous values of river channel gradient (Zuchiewicz 1998).

\subsection{Knickpoints and longitudinal profiles}

The majority of the analyzed river longitudinal 
profiles show shape similar to the line of equilibrium (Figure 10), suggesting recent relative stability of the Sola River catchment and corroborate low tectonic activity in this area. Transient long profiles obtained for short rivers can be related to the low intensity of the erosive force of this type of rivers (Schumm et al. 2000). Observed breaks in long profile lines could be related to local acceleration in tectonic activity (an active crustal fault with long recurrence period), as well as local variations in lithologic or climatic conditions (e.g., Schumm et al. 2000; Kirby and Whipple 2012; Gaidzik and Ramírez-Herrera 2017; Ramírez-Herrera et al. 2018).

We distinguished 53 knickpoints along the Sola River and its 24 main tributaries that reflect the interactions between lithologic, climatic, and tectonic factors (Figure 11). About half of them are located $<500 \mathrm{~m}$ from the nearest fault, and c. $80 \%$ if we include also interpreted lineament pattern, suggesting their possible relation to the stated fault network (Figure 11B). Especially the development of 12 knickpoints located $<200 \mathrm{~m}$ to the nearest fault could be associated with their presence, either as passive or active control (e.g., Giaconia et al. 2012; Gaidzik and Ramírez-Herrera 2017). Moreover, these knickpoints occur mainly in the Beskid Żywiecki Mts. and adjacent to the Soła Gorge (Figure 11B), thus areas with higher relative tectonic activity based on previously presented geomorphometric indices. Knickpoints clustering at a similar elevation a.s.l. might have been produced by changes in the base-level of the entire Sola River catchment that could be related to climatic or tectonic factors. However, in areas of low tectonic strain, considerable variations in baselevel caused by tectonic activity are not likely. On the other hand, climatically driven changes in baselevel took place a few times during the Quaternary as a result of the ice cap migration in the northern part of the study area during glacial/interglacial cycles (Marks 2011). Such changes in base-level can be transmitted to the river profiles of the main river and its tributaries resulting in a set of knickpoints at comparable elevations (e.g., Kirby and Whipple 2012; Gaidzik and Ramírez-Herrera 2017). Using the spatial distribution of recorded knickpoints, river longitudinal profiles, and SL values, we identified one transient wave (15 knickpoints at elevations ranging between 570 and
$620 \mathrm{~m}$ a.s.l.) of incision propagating through the system that could denote the occurrence of such an event related to this process (Figure 11A). The second group including only 7 knickpoints (620 $670 \mathrm{~m}$ a.s.l.) is too small to make reliable conclusions on their nature using variations in a base-level (Figure 11A).

\subsection{Potential neotectonic activity}

We found a few examples of offset channels in the Sola River catchment (Figure 13) that in the areas of high tectonic activity are usually interpreted as the evidence of strike-slip fault displacements (e.g., Gaidziket al. 2016; Reitman et al. 2019). Presented examples do not coincide with the variations in lithology, but in most of the cases, these also do not follow the recorded fault network. The offset channel in the central-eastern part of the study area, within the Glinne catchment, suggests the activity of the NW-trending sinistral strike-slip fault (Figure 13B). This area is built mainly of thick-bedded sandstones and conglomerates intercalated with shales and thin-bedded sandstones of the Magura Nappe. The other offset channel in the eastern part of the study area, within the Łękawka catchment, on the southern slopes of the Beskid Mały Mts., shows potential sublatitudinal dextral strike-slip faults disturbing rivers flowing to the south (Figure $13 \mathrm{C}$ ). Observed river deflections vary from $<50 \mathrm{~m}$ to $>300 \mathrm{~m}$, which might implicate several stages of fault activity (e.g., Reitman et al. 2019). In the eastern part, the proposed structure follows the trace of a previously detected fault (Figure $13 \mathrm{C}$ ). Shales, sandstones, and conglomerates of the Silesian Nappe occur in the $\mathrm{N}$ and build the mountain ridges $(700-850 \mathrm{~m}$ a.s.l.), while sandstones and shales of the Dukla Nappe are present in the $S$ and form the bottom of the Łękawka Valley $(500-600$ $\mathrm{m}$ a.s.l.). The trace of the proposed potentially active structure does not coincide with the contact of these two units. However, further studies, especially paleoseismological, are needed to confirm the Quaternary activity of these faults.

\subsection{Factors controlling relief development in the Sola River catchment}

The intensity of processes causing long-term 
changes in relief is controlled mainly by climatic, topographic, lithologic, and tectonic factors (e.g., Schumm et al. 2000). Observed variations in values of calculated geomorphometric indices can be the result of each of these factors or their combination.

Spatial variability of climate in the Sola River catchment is conditioned primarily by the topographic factor (i.e., elevation a.s.l.; Figure $3 \mathrm{~B}$ ). The climatic changeability of the study area fits within one climatic zone (Wypych et al. 2018). Climate could influence the relief development mainly during short-term extreme events (i.e., torrential rainfalls) (Łajczak et al. 2014) and long-term events (i.e., temperature fluctuations between glacial and interglacial periods) (Marks 2011; Starkel 2017). It is likely that the cluster of 15 knickpoints at elevation range $570-620 \mathrm{~m}$ a.s.l. is related to such event and the resulting drop of regional base-level, which led to the transient wave of incision propagating through the system (Figure 11B). Torrential rainfalls, on the other hand, could trigger mass movement processes leading to valley damming and consequently producing knickpoints. However, other presented anomalies do not seem to be related to climate variations.

Landscape analysis reveals that the relief of the Sola River catchment is partially also controlled by lithology, i.e., rock resistance (Wójcik et al. 2006; Jankowski and Margielewski 2014). A nearly complete absence of crystalline rocks in the Sola River catchment
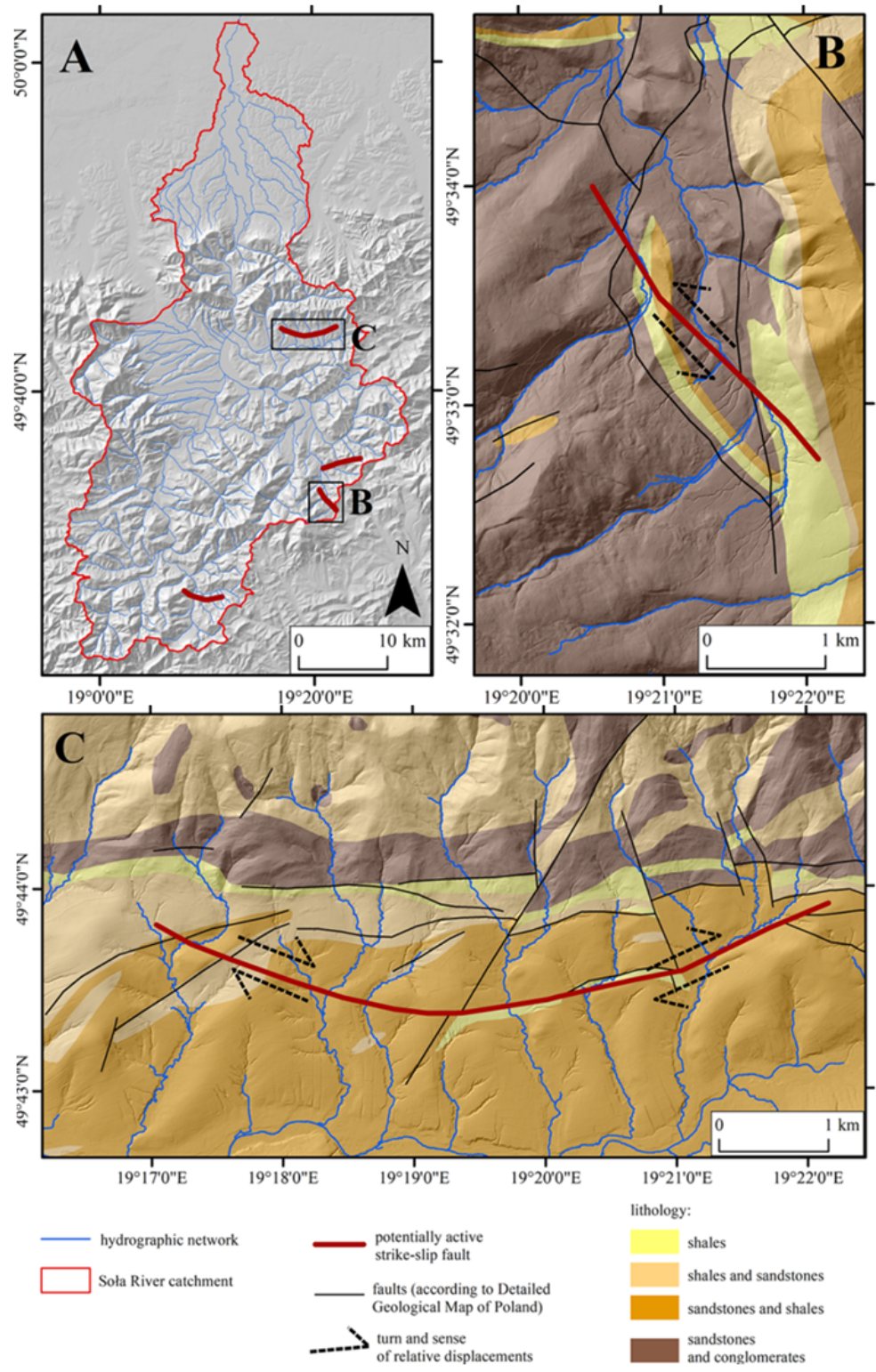

Figure 13 Examples of recorded river off-sets and deflections. A location of detailed maps shown in Figure 13 B and C. B - potential NW-striking sinistral strike-slip fault deflecting streams on the slopes of the Pilsko Massif within sandstones and conglomerates of the Magura Nappe, C - W-striking lineaments dextrally off-setting streams in the E part of the Soła basin, close to Łękawka Valley within sandstones and shales. causes a lack of significant differences in erosive vulnerability of rocks. Nevertheless, differences in resistance among sedimentary rocks can exert influence on relief development (Jankowski and Margielewski 2014). The most susceptible to destructive processes in the Sola River catchment are shales, whereas conglomerates are the most resistant (Oszczypko 2004; Oszczypko et al. 2008). For example, a highly elevated area of the Beskid Śląski Mts. (Figure 1C) built predominantly from sandstones and conglomerates (Figure 4B) shows a lack of dense fault network (Figure 5) and generally low values of the minimum bulk erosion (Figure 12A). The Łękawka catchment (Table 1 and Figure 8), on the other hand, with a predominance of shales and sandstones (Figure 4B), is located in the intramountainous depression with dense fault network (Figures 5 and $7 \mathrm{~B}$ ). Lithological differences can 
explain the formation of some of the recorded knickpoints (Figure 11A), but not the observed anomalies in other geomorphometric indices, especially the minimum bulk erosion.

Thus, the processes of relief development in the Sola catchment appear to be primarily controlled by inherited tectonic structures and processes. We found evidence for the significant influence of tectonic structures (i.e., nappes, thrusts and faults, folds) on the development of river network, spatial distribution, and directions of mountain ranges, location of intra-mountain basins, etc. Currently, tectonic activity does not play a dominant role in the shaping of the relief in the Sola River catchment; nevertheless, its presence should not be excluded. Recorded anomalies in values of calculated geomorphometric indices suggest variations in rock uplift rates. Observed channel offsets imply the possibility of the existence of active strike-slip faults. The Late Neogene and Quaternary fault activity in the low mountains of moderate relief of the Carpathians was corroborated by the presence of fractured clasts (Tokarski and Świerczewska 2005; Tokarski et al. 2007, 2016; Zuchiewicz et al. 2011). The recent tectonic activity was also suggested based on the analysis of river longitudinal profiles and drainage anomalies (Zuchiewicz 1998; Zuchiewicz et al. 2002, 2009; Płaczkowska 2014), the analysis of river terraces (Olszak 2011), paleomagnetism (Tokarski et al. 2016) and the analysis of Neogene and Quaternary gravels (Tokarski et al. 2012). Even seismic activity, although generally of small magnitude and with long return periods, has been proven by instrumental and historical records (Guterch 2009; Plesiewicz and Wiszniowski 2015).

Spatial variations in relative rock uplift rates within the Sola catchment constrained by our landscape analysis result from the current stress field within the nappes of the Outer Carpathians and the autochthonous basement produced by the tectonic push of the Alcapa (Alpine-CarpathianPannonian) microplate exerted on the topof the underthrust European plate (Jarosiński 1998). This tectonic push causes compressive reactivation of the Carpathians leading to the NNE-oriented maximum horizontal stress $\left(\mathrm{S}_{\mathrm{Hmax}}\right)$ in the nappes of the Western Outer Carpathians (Jarosiński 1998, 2005, 2006; Fig. 4A), while the basement undergoes extension (Jarosiński 1998, 2006). The relative movement between these two plates in the western part is accommodated along the NEstriking active Mur-Žilina Fault Zone with an average sinistral displacement rate of $0.3 \mathrm{~mm} / \mathrm{yr}$, as constrained by geodetic measurements and by earthquake focal mechanism data (Aric 1981; Tomek 1988; Figure 4A). The kinematics of proposed possible active strike-slip faults (Fig. 13) does not seem to correspond with the NNE-SSW direction of the maximum horizontal stress $\left(\mathrm{S}_{\mathrm{Hmax}}\right)$ constrained by breakout measurements (Figure 4A). However, the activity of these structures, together with the interpreted WNW- to NWstriking normal faults constrained by triangular facets (Figures 2B, 6E, and $7 \mathrm{C}$ ) could be related to NE-SW directed extension proposed for the autochthonous basement and the western block of the Mur-Žilina Fault Zone (Jarosiński 1998, 2005, 2006; Figure 4A). Similarly oriented local-scale normal faults, commonly interpreted as the Tertiary structures reactivated in the Quaternary, have been reported in other areas of the Outer Carpathians (e.g., Tokarski 1978; Oszczypko 1979; Zuchiewicz et al. 2011). Thus, suspected faults constrained in this study by the landscape analysis could be produced in the nappe pile or be reactivated basement structures, copied in the thin-skinned nappe cover. Either produced or reactivated, these strike-slip faults, are probably the result of the accommodation of the Mur-Žilina Fault Zone.

Potential tectonic activity in this area suggested by our landscape analysis and corroborated by other studies for different areas in the Outer Carpathians (e.g.,Zuchiewicz 1998; Zuchiewicz et al. 2002, 2009, 2011; Tokarski and Świerczewska 2005; Tokarski et al. 2007, 2012, 2016; Guterch 2009; Olszak 2011; Płaczkowska 2014; Plesiewicz and Wiszniowski 2015) might have important implications for the geohazard estimations. Polish Outer Carpathians are prone to landslides due to lithological setting (Oszczypko 2004). Mass movements here are controlled by structural settings (Margielewski 2006) and can be triggered by heavy rainfall or tectonic activity (Wistuba et al. 2018). As demonstrated, even low magnitude earthquakes can lead to the formation of a landslide (Keefer 1984; Wolter et al. 2016). Hence, the determination of areas with potentially increased tectonic activity can improve efficiency in 
estimations of geohazard related to mass movement processes.

\section{Conclusions}

1) Landscape analysis using digital elevation models and GIS techniques facilitates the assessment of the influence of tectonic structures on relief development and provides the estimation of relative tectonic activity in a given area.

2) Inherited tectonic structures play a significant role in the relief development of the Soła River catchment, i.e., directions of principal ridges and valleys follow the orientation of main folds and faults recorded in this area.

3) The areas with potentially higher relative tectonic uplift include the Sola Gorge and the Beskid Żywiecki Mts., as corroborated by anomalously high values of the minimum bulk erosion, river gradient, and stream-length gradient index, relief ratio, circulatory ratio, elongation ratio, and hypsometric integral.

4) The role of recent tectonic activity in relief development of the Sola River catchment appears to be subsidiary at the most.

5) Observed bends in the river valleys direction that do not correspond with changes in lithology could be related to active strike-slip faults.

6) Suspected faults constrained by the landscape analysis are probably the reactivated basement structures, copied in the thin-skinned nappe cover, as a result of the accommodation of

\section{References}

Anand AK, Pradhan SP (2019) Assessment of active tectonics from geomorphic indices and morphometric parameters in part of Ganga basin. Journal of Mountain Science 16(8): 1943-1961. https://doi.org/10.1007/s11629-018-5172-2

Aric K (1981) Deutungkrusten seismischer und seismologisher Ergebnisse in Zusammenhänge mit der Tektonik des Alpenostrandes. Aus den Sitzungsberichten der Öesterr. Acad. Wiss. Mathem. Naturw. Kl., Wien 190 (8-10): 235-312. (In Polish)

Argyriou AV, Teeuw RM, Soupios P, Sarris A (2017) Neotectonic control on drainage systems: GIS-based geomorphometric and morphotectonic assessment for Crete, Greece. Journal of Structural Geology 104: 93-111. https://doi.org/10.1016/j.jsg.2017.10.002

Badura J, Zuchiewicz W, Górecki A, et al. (2003) Morphometric characteristics of the Sudetic Marginal Fault between Złoty Stok and Dobromierz, SW Poland. Przegląd Geologiczny 51(12): 1048- the Mur-Žilina Fault Zone.

7) Spatial variations in relative rock uplift rates within the Sola catchment result from the current stress field within the nappes of the Outer Carpathians and the autochthonous basement produced by the tectonic push of the Alcapa (Alpine-Carpathian-Pannonian) microplate against the European plate.

8) Further studies using geophysical and paleoseismological methods, together with geochronological dating are needed to confirm the actual impact of the Quaternary tectonic activity (especially active faults) on relief development in the study area.

\section{Acknowledgments}

The authors would like to thank the editor and the two anonymous reviewers for providing comments and suggestions that helped to improve our manuscript.

Open Access This article is distributed under the terms of the Creative Commons Attribution 4.0 International License (http://creativecommons.org/licenses/by/4.o/), which permits unrestricted use, distribution, and reproduction in any medium, provided you give appropriate credit to the original author(s) and the source, provide a link to the Creative Commons license, and indicate if changes were made.

1057.

Brocklehurst SH, Whipple KX (2002) Glacial erosion and relief production in the Eastern Sierra Nevada, California. Geomorphology 42(1): 1-24.

https://doi.org/10.1016/So169-555X(01)ooo69-1

Buczek K, Górnik M (2020) Evaluation of tectonic activity using morphometric indices: case study of the Tatra Mts. (Western Carpathians, Poland). Environmental Earth Sciences 79: 1-13. https://doi.org/10.1007/s12665-020-08912-9

Bull WB, McFadden LD (1977) Tectonic geomorphology north and south of the Garlock fault, California. In: Doehring DO (Ed.) Geomorphology in Arid Regions. Proceedings of the 8th Annual Geomorphology Symposium. State University of New York at Binghampton. 9: 115-138

Burbank DW, Anderson RS (2001) Tectonic Geomorphology. Willey-Blackwell, Hoboken.

Computer Map of Hydrographic Division of Poland (2019) 
Rivers.https://dane.gov.pl/dataset/869,komputerowa-mapapodziau-hydrograficznegopolski/resource/18194/table (Accessed on 15 October 2019).

Czajka W (2009) Database of the terrain elevations in DTED format. BELLONA (special issue). Ministry of Defence, Warsaw: 26-30. (In Polish)

Detailed Geological Map of Poland (2019) Sheets: Wisła (1028), Milówka (1029), Jeleśnia (1030), Bielsko-Biała (1012), Skoczów (1011), Kęty (993), Wadowice (994), Lachowice (1013), Ujsoły (1046). National Geological Institute - National Research Institute, Warsaw.

https://geolog.pgi.gov.pl/\#name=kob3odgo43 (Accessed on 15 September 2019)

Digital Terrain Elevation Data Level 2 (2004) Faculty of Design and Implementation, Military Centre of Geodesy and Remote Sensing, Polish Army, Warsaw.

Eagleson PS (1970) Dynamic Hydrology. McGraw-Hill Book Company, New York, 462.

ESRI - Environmental Systems Research Institute (2018) ArcGIS Desktop: version 10.7.1, Redlands, CA.

Font M, Amorese D, Lagarde JL (2010) DEM and GIS analysis of the stream gradient index to evaluate effects of tectonics: the Normandy intraplate area (NW France). Geomorphology 119(34): 172-18o.https://doi.org/10.1016/j.geomorph.2010.03.017

Gaidzik K, Ramírez-Herrera MT (2017) Geomorphic indices and relative tectonic uplift in the Guerrero sector of Mexican forearc. Geoscience Frontiers 8: 885-902.

https://doi.org/10.1016/j.gsf.2016.07.006

Gaidzik K, Ramírez-Herrera MT, Kostoglodov V (2016) Active crustal faults in the forearc region, Guerrero sector of the Mexican subduction zone. Pure and Applied Geophysics 173 (10-11): 34193443. https://doi.org/10.1007/sooo24-015-1213-8

Galay VJ (1983) Causes of river bed degradation. Water resources research 19 (5): 1057-1090.

https://doi.org/10.1029/WRo19ioo5p01057

Gao M, Zeilinger G, Xu X, et al. (2013). DEM and GIS analysis of geomorphic indices for evaluating recent uplift of the northeastern margin of the Tibetan Plateau, China. Geomorphology 190: 61-72.

https://doi.org/10.1016/j.geomorph.2013.02.008

García-Delgado H, Velandia F (2020). Tectonic geomorphology of the Serranía de San Lucas (Central Cordillera): Regional implications for active tectonics and drainage rearrangement in the Northern Andes. Geomorphology 349: 106-914. https://doi.org/10.1016/j.jsames.2019.102472

Giaconia F, Booth-Rea G, Martínez-Martínez JM, et al. (2012) Geomorphic evidence of active tectonics in the Sierra Alhamilla (eastern Betics, SE Spain). Geomorphology 145: 90-106.

https://doi.org/10.1016/j.geomorph.2011.12.043

Ghosh S, Paul AK (2020): Tectonic control over drainage basin of South Andaman Island: study toward hydro-morphometric analysis. Applied Water Science 10(1): 5 .

https://doi.org/10.1007/s13201-019-1055-0

Guterch B (2009) Seismicity in Poland in the light of historical records. Przegląd Geologiczny 57(6): 513-520. (In Polish).

Hack JT (1973) Stream profiles analysis and stream-gradient index. Journal Research U.S. Geological Survey 1(4): 421-429. https://pubs.usgs.gov/journal/1973/voliissue4/report.pdf\#page=49

IMWM - NRI - Institute of Meteorology and Water Management National Research Institute (2020) Meteorological survey observational data.

https://dane.imgw.pl/data/dane_pomiarowo_obserwacyjne/da ne_meteorologiczne/

Jankowski L, Margielewski W (2014) Structural Control on the Outer Carpathians relief - a new approach. Przegląd Geologiczny 62(1): 29-35.

Jarosiński M (1998) Contemporary stress field distortion in the Polish part of the Western Outer Carpathians and their basement. Tectonophysics 297: 91-119.

Jarosiński M (2005) Ongoing tectonic reactivation of the Outer Carpathians and its impact on the foreland: results of borehole breakout measurements in Poland. Tectonophysics, 410 (1-4):
189-216. https://doi.org/10.1016/j.tecto.2004.12.040

Jarosiński M (2006) Recent tectonic stress field investigations in Poland: a state of the art. Geological Quarterly $50(3): 303-321$.

Keefer DK (1984) Landslides caused by earthquakes. Geological Society of America Bulletin 95: 406-421.

Keller EA, Pinter N (2002) Active Tectonics: Earthquakes, Uplift, and Landscape, second ed. New Jersey, $432 \mathrm{pp}$.

Kirby E, Whipple KX (2001) Quantifying differential rock-uplift rates via stream profile analysis. Geology 29 (5): 415-418. https://doi.org/10.1130/o0917613(2001)029\%3Co415:QDRURV\%3E2.0.CO;2

Kirby E, Whipple KX (2012) Expression of active tectonics in erosional landscapes. Journal of Structural Geology 44: 54-75. http://doi.org/10.1016/j.jsg.2012.07.009

Ksiazzkiewicz M (1977) The tectonics of the Carpathians. In: Pożaryski W (Ed.) Geology of Poland 4. Wydawnictwa Geologiczne, Warsaw: $476-620$.

Kubiak M, Stach A (2013) Influence of relief and land cover on the distribution of values of the land surface temperature in upper Parsęta river area. QuaestionesGeographicae 32(3): 39-51. https://doi.org/10.2478/quageo-2013-0022

Lama S, Maiti R (2019) Morphometric Analysis of Chel River Basin, West Bengal, India, using Geographic Information System. Earth Science India 12(1): 1-23. https://doi.org/10.31870/ESI.12.1.2019.01

Łajczak A, Margielewski W, Rączkowska Z, Świechowicz J (2014) Contemporary geomorphic processes in the Polish Carpathians under changing human impact. Episodes 37(1): 21-32.

Margielewski W (2006) Structural control and types of movements of rock mass in anisotropic rocks: case studies in the Polish Flysch Carpathians. Geomorphology 77(1-2): 47-68. https://doi.org/10.1016/j.geomorph.2006.01.003

Marks L (2011) Quaternary glaciations in Poland. Developments in Quaternary Sciences 15: 299-303. https://doi.org/10.1016/B978-0-444-53447-7.00023-4

Matoš B, Tomljenoviæ B, Trenc N, (2013) Identification of tectonically active areas using DEM: a quantitative morphometric analysis of Mt. Medvednica, NW Croatia. Geological Quarterly 58 (1): 51-70. https://doi.org/10.7306/gq.1130

Miller VC (1953). Quantitative geomorphic study of drainage basin characteristics in the Clinch Mountain area, Virginia and Tennessee. Technical report (Columbia University. Department of Geology), 3

Nescieruk P, Wójcik A (2013) Explanations for the Detailed Geological Map of Poland 1:50 ooo.Sheet Bielsko-Biała (1012). Geological Publishing House, Warsaw.

http://bazadata.pgi.gov.pl/data/smgp/arkusze_txt/smgp1012.pdf (In Polish)

Olszak J (2011) Evolution of fluvial terraces in response to climate change and tectonic uplift during the Pleistocene: Evidence from Kamienica and Ochotnica River valleys (Polish OuterCarpathians). Geomorphology 129(1-2): 71-78. https://doi.org/10.1016/j.geomorph.2011.01.014

Oszczypko N (1979) Budowa geologiczna północnych stoków Beskidu Sądeckiego między Dunajcem a Popradem (płaszczowina magurska). Rocznik Polskiego Towarzystwa Geologicznego 49: 293-325. (in Polish).

Oszczypko N (2004) The structural position and tectonosedimentary evolution of the Polish Outer Carpathians. Przegląd Geologiczny 52(8/2): $780-791$.

Oszczypko N, Ślaczka A, Żytko K (2008). Tectonic subdivision of Poland: Polish Outer Carpathians and their foredeep. Przegląd Geologiczny 56(10): $927-935$.

Pánek T (2004) The use of morphometric parameters in tectonic geomorphology (of the example of the Western Beskidy Mts). Acta Universitatis Carolinae, Geographica 1: 111-126.

Pawluszek K, Borkowski A (2017) Impact of DEM-derived factors and analytical hierarchy process on landslide susceptibility mapping in the region of Rożnów Lake, Poland. Natural Hazards 86(2): 919-952. https://doi.org/10.1007/s11069-016-2725-y

Pérez-Peña JV, Azor A, Azañón JM, Keller EA (2010) Active tectonics in the Sierra Nevada (Betic Cordillera, SE Spain): in- 
sights from geomorphic indexes and drainage pattern analysis. Geomorphology 119: 74-87. https://doi.org/10.1016/j.geomorph.2010.02.020

Pike RI, Wilson SE (1971) Elevation relief ratio, Hypsometric integral and geomorphic area altitude analysis. Geol. Soc. Am. Bull. 82: 1079-1084.

Płaczkowska E (2014) Geological aspects of headwater catchments development in the Lubań Range (the Outer Carpathians, Poland). Zeitschrift für Geomorphologie 58(4): 525-537. https://doi.org/10.1127/0372-8854/2014/0143

Plesiewicz B, Wiszniowski J (2015) Seismicity of Polish part of the Western Carpathians in the light of recent data. In: Studies of Historical Earthquakes in Southern Poland. Springer, Cham: 103118. https://doi.org/10.1007/978-3-319-15446-6_4

QGIS Development Team (2019) QGIS (Geographic Information System v. 3.8). Open Source Geospatial Foundation Project. http://qgis.osgeo.org

Ramírez-Herrera MT, Gaidzik K, et al. (2018) Relating the longterm and short-term vertical deformation across a transect of the forearc in the central Mexican subduction zone. Geosphere 14(2): 419-439. https://doi.org/10.1130/GESo1446.1

Reitman NG, Mueller K., Tucker GE, Gold RD, Briggs RW, Barnhart KR (2019) Offset channels may not accurately record strike-slip fault displacement: Evidence from landscape evolution models. Journal of Geophysical Research: Solid Earth.

https://doi.org/10.1029/2019JB018596

Różycka M, Migoń P (2017) Tectonic geomorphology of the Sudetes (Central Europe) - a review and re-appraisal. Annales Societatis Geologorum Poloniae 87(4): 275-300.

https://doi.org/10.14241/asgp.2017.016

Ruszkiczay-Rüdiger Z, Fodor L, Horváth E, Telbisz T (2009) Discrimination of fluvial, eolian and neotectonic features in a low hilly landscape: a DEM-based morphotectonic analysis in the Central Pannonian Basin, Hungary. Geomorphology 104: 203217. https://doi.org/10.1016/j.geomorph.2008.08.014

Ryłko W, Paul Z (2013) Explanations for the Detailed Geological Map of Poland 1:50 ooo. Sheet Lachowice (1013). Geological Publishing House, Warsaw.

http://bazadata.pgi.gov.pl/data/smgp/arkusze_txt/smgp1013.pdf (In Polish)

Schumm S, Dumont J, Holbrook J (2000) Active Tectonics and Alluvial Rivers. Cambridge University Press, Cambridge.

Starkel L (2017) The remarks on the polygenesis of mountain relief (exemplified by the Carpathians). Acta Geographica Lodziensia 106: 31-35. https://doi.org/10.26485/AGL/2017/106/3

Štěpančíková P, Dohnal J, Pánek T, et al. (2011) The application of electrical resistivity tomography and gravimetric survey as useful tools in an active tectonics study of the Sudetic Marginal Fault (Bohemian Massif, central Europe). Journal of Applied Geophysics 74: 69-80.

https://doi.org/10.1016/j.jappgeo.2011.03.007

Štěpančíková P, Hók J, Nývlt D, et al. (2010) Active tectonics research using trenching technique on the south-eastern section of the Sudetic Marginal Fault (NE Bohemian Massif, central Europe). Tectonophysics 485(1-4): 269-282. https://doi.org/10.1016/j.tecto.2010.01.004

Strahler AN (1964) Quantitative geomorphology of drainage basin and channel networks. In: Chow VT (Ed.) Handbook of Applied Hydrology. McGraw-Hill, New York. pp 439-476.

Tokarski AK, Márton E, Świerczewska A, Fheed A, Zasadni J, Kukulak J (2016) Neotectonic rotations in the Orava-Nowy Targ Intramontane Basin (Western Carpathians): An integrated palaeomagnetic and fractured clasts study. Tectonophysics 685 : 35-43. https://doi.org/10.1016/j.tecto.2016.07.013

Tokarski AK (1978) O czwartorzędowym ciosie i uskoku w Kotlinie Sądeckiej (Zachodnie Karpaty Zewnętrzne). Rocznik Polskiego Towarzystwa Geologicznego 48: 509-516. (In Polish)

Tokarski AK, ŚwierczewskaA (2005) Neofractures versus inherited fractures in structural analysis: a case study from Quaternary fluvial gravels (Outer Carpathians, Poland). Annales Societatis Geologorum Poloniae 75(1): 95-104.
Tokarski AK, Świerczewska A, Zuchiewicz W (2007). Fractured clasts in neotectonic reconstructions: an example from the Nowy Sacz basin, western outer Carpathians, Poland. Studia Quaternaria 24: 47-52.

Tokarski AK, Świerczewska A, Zuchiewicz W, et al. (2012). Quaternary exhumation of the Carpathians: a record from the Orava-Nowy Targ Intramontane Basin, Western Carpathians (Poland and Slovakia). Geologica Carpathica 63: 257-266. https://doi.org/10.2478/v10096-012-0021-7

Tomek C (1988) Geophysical investigation of the Alpine-Carpathian Arc. In: Evolution of the Northern Margin of Tethys, 1. Mem. Soc. Geol. France, Paris, Novelle Serie 154: 167-200.

Vojtko R, Petro LU, Benová A, Bóna J, Hók J (2012) Neotectonic evolution of the northern Laborec drainage basin (northeastern part of Slovakia).Geomorphology 138(1): 276-294. https://doi.org/10.1016/j.geomorph.2011.09.012

Wang S, Ren Z, Wu C, et al. (2019) DEM generation from Worldview-2 stereo imagery and vertical accuracy assessment for its application in active tectonics. Geomorphology 336, 107-118. https://doi.org/10.1016/j.geomorph.2019.03.016

Wistuba M, Malik I, Krzemień K, et al. (2018) Can low-magnitude earthquakes act as a triggering factor for landslide activity? Examples from the Western Carpathian Mts, Poland. Catena 171: 359-375. https://doi.org/10.1016/j.catena.2018.07.028

Wójcik A, Mrozek T, Granoszewski W (2006) Lithological conditioning of landslides and climatic changes with examples from the Beskidy Mts., Western Carpathians, Poland. Geografia Fisica e Dinamica Quaternaria 29: 197-200.

Wołosiewicz B (2018) The influence of the deep seated geological structures on the landscape morphology of the Dunajec River catchment area, Central Carpathians, Poland and Slovakia. Contemporary Trends in Geoscience 7(1): 21-47. https://doi.org/10.2478/ctg-2018-0002

Wolter A, Gischig V, Stead D, Clague JJ (2016) Investigation of Geomorphic and Seismic Effects on the 1959 Madison Canyon, Montana, Landslide Using an Integrated Field, Engineering Geomorphology Mapping, and Numerical Modelling Approach. Rock Mechanics and Rock Engineering 49: 2479-2501. https://doi.org/10.1007/s00603-015-0889-5

Wypych A, Ustrnul Z, Schmatz, DR (2018) Long-term variability of air temperature and precipitation conditions in the Polish Carpathians. Journal of Mountain Science 15(2): 237-253. https://doi.org/10.1007/s11629-017-4374-3

Wyżga B, Zawiejska J, Hajdukiewicz H (2016) Multi-thread rivers in the Polish Carpathians: occurrence, decline and possibilities of restoration. Quaternary International 415: 344-356. https://doi.org/10.1016/j.quaint.2015.05.015

Van Rossum G, Drake FL (2009) Python 3 Reference Manual. Scotts Valley, CA: Create Space.

Yong Technology Inc. (2014) GeoRose. Edmonton, Canada. http://www.yongtechnology.com/download/georose

Zuchiewicz W (1998) Quaternary tectonics of the outer West Carpathians, Poland. Tectonophysics 297(1-4): 121-132. https://doi.org/10.1016/Soo4O-1951(98)oo226-1

Zuchiewicz W, Tokarski AK, Jarosiński M, Marton E (2002) Late Miocene to present day structural development of the Polish segment of the Outer Carpathians. EGU Stephan Mueller Special Publication Series 3: 185- 202.

https://doi.org/10.5194/smsps-3-185-2002

Zuchiewicz W, Tokarski AK, Świerczewska A, Cucong NQ (2009) Neotectonic activity of the Skawa River Fault Zone (Outer Carpathians, Poland). Annales Societatis Geologorum Polonae 79(1): 67-93.

Zuchiewicz W, Tokarski AK, Świerczewska A, et al. (2011) First site of Holocene faults in the Polish Outer Carpathians. Przegląd Geologiczny 59, 566-575.

Żytko K, Zając R, Gucik S, et al. (1989) Map of the tectonic elements of the Western Outer Carpathians and their foreland. In: Poprawa D, Nemčok J (eds.) Geological atlas of the Western Outer Carpathians and their foreland. Wydawnictwa Geologiczne, Warszawa. 